\title{
EL DOMINIO SOLARIEGO Y TERRITORIAL EN EL MARCO LOS SEÑORIOS NOBILIARIOS LEONESES. Rentas, derechos y conflicto judicial en los estados del Conde de Miranda a finales del Antiguo Régimen.
}

\author{
LAUREANO M. RUBIO PÉREZ
}

\section{Resumen}

El presente trabajo trata de analizar la situación creada en el marco de los señoríos por los diferentes decretos que, partiendo de las Cortes de Cádiz de 1811, pusieron fin al régimen señorial, aunque, tal como se comprueba en el presente caso, la cuestión no quedaba cerrada ya que desde su complejidad se mantenían, al margen del jurisdiccional abolido, otros dominios como el solariego y territorial. Partiendo de esa situación se estudia el dominio señorial que la casa Miranda mantuvo al sur de la provincia leonesa y en tierras bañezanas, y de forma especial el pleito que dicha casa mantuvo con el Estado durante la primera mitad del siglo XIX por el reconocimiento de sus dominios solariego y territorial. La propia documentación aportada por la parte demandante nos permitió conocer por dentro la dimensión e implantación social y económica del señorío a lo largo de la Edad Moderna, así como el desenlace de sus relaciones vasalláticas durante esos años clave de principios del siglo XIX.

\section{Palabras clave}

Señorío, jurisdicción, dominio solariego, dominio territorial, fuero, martiniega, alcabala, renta señorial, foro, concejo, justicia pedánea, heredades, Real Carta Ejecutoria.

\begin{abstract}
This paper tries to analize the situation created in the framework of various territories by the several decrees that, coming from the "Cortes" (Parliament) of Cadiz in 1811, meant the end for the regime similar to he English manorial one, though, as it is shown in the present case, the issue was not definitely settled since, due to their complexity, other domains like the "solariego" and territorial ones were maintained indipendently from the jurisdictional regime, which was abolished. Starting from that situation, we analize the "dominio señorial" that the House of Miranda held in the south of the province of León and in the district around La Bañeza and, in a special way, the lawsuit which that House brought against the State along the first part of the $19^{\text {th }}$ century over the acknowledgement of their "solariego" and territorial domains. The documentation afforded by the plaintiffs allowed us to learn from the inside the dimension and the social and economic establisment of that estate throughout the Modern Age, as well as the end of its vassalage relationships during those key years of the early $19^{\text {th }}$ century.
\end{abstract}

\section{Key words}

Domain, jurisdiction, "dominio solariego", charter, privileges, "martiniega" (tax payable on St. Martin's day or around that time), "alcabala" 
(a sort of tallage), manorial income, "foro" (leasehold), "concejo" (council), "justicia pedánea" (council justice), estates, Royal Letters Patent of Nobility.

\section{El señorío: jurisdicción, solar y territorio.}

El estudio del régimen señorial y de las relaciones que durante más de cinco siglos mantuvieron las sociedades campesinas con los señores es harto complejo no tanto por la formulación teórica más o menos aceptada en torno a los conceptos básicos, cuanto por la heterogeneidad existente en la práctica y desde la vinculación concreta de cada señorío al territorio, en el que se asienta como unidad político-administrativa, y a la base social sobre la que se impone. El avance en el conocimiento del régimen señorial, de su evolución, desarrollo e incidencia se ha de hacer, sin olvidar el marco teórico común, partiendo de las realidades individuales concretas, toda vez que cada estado señorial, cada dominio, cada comunidad y cada territorio controlado desarrolla su propia dinámica bajo la impronta de los condicionantes de sus bases estructurales. Así pues, la realidad del señorío ha de valorarse desde sus diversas dimensiones: desde la posición de los diferentes componentes extraeconómicos ligados al poder político y judicial; desde el componente socio-económico vinculado a las relaciones vasalláticas y de producción en las que la renta agraria puede alcanzar un papel diferenciador y, como no, desde las realidades externas al propio poder señorial y presentes en el marco territorial y social sobre el que se desarrolla éste. Esto nos ayudará a alcanzar una visión global más acertada, a entender su evolución y adaptaciones en el tiempo y a las diferentes realidades o a comprender actitudes diferenciales que no siempre han de enfocarse desde la confrontación señores- vasallos, opresores-oprimidos, pues en no pocos momentos esta supuesta confrontación se transforma en colaboración e intereses comunes, especialmente cuando aparece un elemento nuevo en discordia, ya sea el estado, ya cualquier otro grupo de poder. Las comunidades campesinas sometidas al régimen señorial fueron siempre conocedoras y conscientes de la realidad y legalidad de su vinculación al hecho señorial, de lo que ello suponía y de sus derechos e intereses a la hora de establecer y mantener sus relaciones con el poder señoria $_{\text {En }} 1848$ el Duque de Berbie y Alba como esposo de la Condesa de Montijo y Miranda, finalizado el pleito sostenido con el fiscal del Estado, solicita la concesión de una Real Carta Ejecutoria en la que se declarasen los estados de Palacios de Valduerna y su Infantazgo de pro- 
piedad particular como procedentes de señorio territorial y solariego, independientemente del abolido jurisdiccional que conjuntamente habían ejercido hasta el año $1811 .^{1}$

Suponía esto el final de un largo proceso que, remontándose a la Baja Edad Media, no sólo no finalizó a principios del siglo XIX, sino que se complicó a raíz del Decreto de Cortes de 6 de Agosto de 1811 y de las sucesivas leyes aclaratorias por las que se completa la abolición del régimen señorial ${ }^{2}$. El establecimiento en dicho decreto de tres variantes en relación al carácter del señorío (jurisdiccional, solariego y territorial) no sólo generó confusión, sino que motivó el establecimiento por parte de la historiografía de diferentes tipos de señorío ${ }^{3}$ frente a la posición, hoy más o menos asumida, de que tan sólo cabe hablar de un único tipo de señorío en torno al poder jurisdiccional recibido por los señores de manos del rey, en tanto en cuanto es la jurisdicción alta y baja, mero e mixto imperio la que conforma la realidad social, política y económica del régimen señorial. ${ }^{4}$ Pero, en realidad lo que parece reflejar la nueva legislación no es una supuesta distinción entre señoríos jurisdiccionales y solariegos, sino recoger las diferencias existentes entre los señores y la heterogeneidad de la realidad señorial en cuanto a las diferentes formas de participación en la tierra y en las rentas agrarias, así como de garanti-

\footnotetext{
${ }^{1}$ Archivo Municipal de Palacios de Valduerna. Real Carta Ejecutoria de los Estados de Palacios e Infantazgo de Valduerna.

${ }^{2}$ Junto al Decreto de Cortes de 1811 se hace referencia a la nueva ley sobre señoríos de 1823 , de la cual se dice que es perjudicial a los intereses de los señores, y a la de 1837 que en cierto modo sirve de apoyo al inicio de este proceso por parte de la condesa de Miranda.

${ }^{3}$ A partir del citado Decreto de 1811 algunos estudios comienzan a referirse a dos o tres tipos de señoríos: :jurisdiccionales, solariegos y mixtos. Este planteamiento puede verse en algunos estudios de Moxó y de Domínguez Ortíz: MOXÓ, S.: La disolución del Régimen señorial en España. Madrid,1965. También: "Los señoríos. En torno a una problemática para el estudio del régimen señorial”, Hispania XXIV, n94 (1964), pp. 185-236. DOMINGUEZ ORTIZ, A. Hechos y figuras del siglo XVIII español, Madrid, 1973.

${ }^{4}$ Un extenso análisis historiográfico en torno al concepto de señorío y su problemática puede verse en: COLAS LATORRE,G. “ La Historiografía sobre el señorío tardofeudal”, en SARASA SANCHEZ, E. Y SERRANO MARTIN,(Eds). Señorío y feudalismo en la Península Ibérica, t.1, pp.51-105. Zaragoza, 1993. En el congreso de Zaragoza en el que se presenta la ponencia citada anteriormente se valoran los componentes extraeconómicos del régimen señorial ligados al poder político y jurídico, incluso muy por encima del componente económico relacionado con la extracción de la renta. La cuestión es compleja, especialmente cuando se trata de valorar y medir la incidencia de la realidad señorial en la sociedad y en la economía campesinas y cuando dicha incidencia puede variar en función de diversos factores y realidades inherentes a cada dominio señorial. Esto hace que mientras que existen casos en los que no se aprecian diferencias al respecto entre sociedades sometidas al señorío y al realengo en otros casos la llegada del señorío nobiliario afectó negativamente a las comunidades campesinas en tanto en cuanto se vieron forzadas a mantener unas relaciones políticas y de producción con los nuevos señores que en el caso de otras comunidades, que se mantienen a partir del siglo XV bajo el realengo, desaparecen o no existen. En este contexto la mayor o menor capacidad de actuación del poder concejil y de contestación de cada comunidad jugó un importante papel, sobre todo durante la Baja Edad Media, para el futuro de las relaciones con los señores. Vid al respecto: L. RUBIO PEREZ. Visitas, juicios de residencia y poder concejil en la Provincia de León. Mecanismos de control en el marco del régimen señorial durante la Edad Moderna. Universidad de León. León, 1998.
} 
zarle el principio fundamental de la propiedad, sin que ello supusiera, tal como se verá en el caso que nos ocupa, la obligación de demostrar la libre propiedad con títulos emanados del mero contrato mercantil. En la práctica, lo que genera el mencionado decreto es una importante confusión a la hora de diferenciar la procedencia de las diferentes rentas, confusión que motivó largos pleitos entre el Estado y unos señores que, como la casa Miranda, sólo pueden demostrar su dominio territorial desde el soporte jurisdiccional y desde los posteriores contratos que, como se verá, imponen bien de mutuo acuerdo, bien mediante la fuerza o coerción, a los vasallos y a las comunidades concejiles. La estrategia de la casa Miranda va a pasar, como se verá más adelante, por demostrar que la propiedad o el dominio solariego y territorial que demandaba era recogida por la nueva legislación referente a la abolición de los señoríos, y por la diferenciación que hace al vincularlo al derecho común que ampara la propiedad particular ${ }^{5}$.

Sin embargo, la distinción hecha por las Cortes, una vez abolido el jurisdiccional y los derechos meramente vasalláticos emanados de él, resulta compleja cuando se trata de valorar y justificar el origen y contenido de esos dos conceptos, solariego y territorial, dado que los legisladores liberales debían de conocer que parte de esos derechos vasalláticos, especialmente la martiniega, habían sido situados por los señores en la Baja Edad Media sobre la tierra, especialmente sobre la tierra comunal y en no pocas ocasiones sobre los diferentes términos de las comunidades que agregados formaban el término o espacio jurisdiccional ${ }^{6}$. Estas acti-

\footnotetext{
${ }^{5}$ Mientras que en el artículo $1^{\circ}$ del Decreto de 1811 se regula que desde ahora quedan incorporados a la nación todos los señoríos jurisdiccionales de cualquier clase o condición que sean, lo que suponía que el Estado recuperaba el poder territorial y las rentas vinculadas a él, en el artículo $5^{\circ}$ al legislar que los señorios territoriales y solariegos quedan desde ahora en la clase de los demás derechos de propiedad particular, se está intentando garantizar a los señores un dominio territorial y un poder económico que habían legitimado durante muchos siglos mediante el jurisdiccional abolido. Esto explica que en el siguiente artículo del mencionado Decreto se aclare que los contratos, pactos o convenios que se hayan hecho en razón de aprovechamientos, arriendos de terrenos, censos u otros de esta especie, celebrados entre los llamados señores y vasallos, se deberán considerar desde ahora como contratos de particular a particular.

${ }^{6}$ En este contexto reformador el caso del señorío valenciano es quien parece generar más problemas a los legisladores de 1811, a juzgar por las referencias del fiscal de este caso, dadas las duras condiciones impuestas por los señores a los colonos que pueden llegar a detraer en concepto de censales o renta la mitad de la producción. Mientras que en la provincia leonesa la nueva nobleza señorial, especialmente el futuro Conde de Luna, desde su condición de Adelantado Mayor de Asturias, aprovechando la crisis política del siglo XV y la debilidad de algunos concejos, logra imponer, aunque de forma muy desigual, estos deberes de pago o censos de frutos (cuartos o quintos) que podían suponer la cuarta parte de la producción, en el caso valenciano la situación se agrava mediante una mayor presión sobre los campesinos. El origen de esta situación hay que situarlo en la E.Media y en la extensión del dominio solariego y territorial de los señores sobre las tierras de los moriscos. Una vez abandonada la tierra por parte de los campesinos, de la misma forma que ocurre en León con los despoblados del siglo XIV y de finales del XVI, los señores se llaman a la propiedad, llegando a hostigar a sus vasallos para que la abandonen o en el mejor de los casos pactando forales enfitéuticos con los
} 
tudes, que en la práctica obtuvieron resultados muy diferentes incluso dentro de un mismo dominio señorial, vienen a demostrar la importancia que tuvo el poder jurisdiccional en manos de la nobleza, especialmente en la etapa bajomedieval, así como la capacidad de respuesta del poder local o concejil. A partir de ese poder y de la debilidad de la monarquía los nuevos señores tendieron pronto a ampliar su dominio solariego y a exigir de las comunidades el reconocimiento de su dominio territorial sobre el término y los recursos no privativos existentes en él, aunque, como se aprecia en el caso que nos ocupa, esas pretensiones señoriales apenas tuvieron éxito en aquellos territorios del Reino de León donde las comunidades concejiles ya estaban plenamente organizadas y arropadas por fueros y por el Derecho Consuetudinario. Así pues, como se demuestra en el ejemplo presente, no cabe separación alguna entre jurisdiccional y territorial, pese a los éxitos judiciales logrados por los señores en el siglo XIX, dado que el elemento solariego y territorial no define por si sólo un tipo específico de señorío, solamente cabría hablar de señorío, sin que el calificativo de jurisdiccional o solariego haga referencia a la existencia de dos tipologías. Esta estrecha vinculación entre el jurisdiccional, el solariego y el dominio territorial aparece en todos los señoríos nobiliarios leoneses formados en su mayoría a partir de las mercedes y concesiones de los reyes de la casa Trastámara y durante una larga fase de fuerte señorialización de la provincia.

Pero, la cuestión fundamental que se plantea y que en modo alguno supieron o pudieron resolver los legisladores del siglo XIX gira en torno al significado real del solariego y territorial, toda vez que aquellos no se percataron o no quisieron percatarse de que el reclamado dominio solariego y territorial no sólo encerraba muchas contradicciones, sino que estaba totalmente vinculado a los títulos jurisdiccionales, interpretados muy particular e interesadamente por ellos. Como ocurre en el caso que nos ocupa y en la mayor parte de los señoríos nobiliarios leoneses, tanto los señores jurisdiccionales, como los propios legisladores, parten de considerar a un lugar o a un territorio señorial como territorial sin que ello suponga que éste tenga la plena propiedad del término o territorio.

\footnotetext{
concejos colindantes a dichos despoblados, lo que en cierto modo suponía reconocerle de hecho el dominio directo. Vid. ARTOLA, M. Antiguo Régimen y Revolución liberal.Barcelona,1983, pág.61. Para un conocimiento más amplio puede verse : RUIZ TORRES, P. "Los señoríos valencianos en la crisis del Antiguo Régimen: una revisión historiográfica", Estudis d'Historia Contemporánia del País Valenciá, 5,1984, pp.23 y ss. Sobre la incidencia y respuesta social del Decreto de 1811 en el territorio valenciano y en el resto de España puede verse: Francisco J.Hernández.La abolición de los señoríos en España, 1811-1837. Madrid, 1999, pp.161-181.
} 
La propiedad de determinados bienes raíces parece otorgarle el derecho a ese dominio solariego, de la misma forma que el reclamado dominio territorial le vincula a una serie de espacios o recursos, generalmente comunales, ahora ya delimitados. ¿Acaso desconocían los legisladores que en no pocos señoríos, ocupados por campesinos propietarios y vasallos libres, estos y los respectivos concejos eran dueños privativos y usufructuarios de la mayor parte de la tierra i. ¿Acaso desconocían los legisladores que tanto los señores valencianos, como los leoneses, se habían apropiado paulatinamente y en la medida de sus diferentes posibilidades de los términos despoblados, de las dehesas roturadas o de aquellos otros espacios o recursos que, como los ríos, aguas, etc., habían estado desde un principio administrados en buena medida por los concejos o gobiernos locales?.

Sin embargo, la clave ahora, tal como se aprecia en el pleito sostenido por el fiscal y la casa Miranda, está en ver si las rentas y foros que percibe la nobleza tienen su origen en el título jurisdiccional o son fruto de un contrato mercantil. Pero, a estas alturas parece claro que algunos señores, entre los que se encuentran los Bazán -Miranda, ya habían dado un importante paso no exento de conflictividad y de una desigual respuesta concejil: obligar a los concejos a suscribir una serie de contratos forales enfitéuticos que sustituían a los antiguos censos y prestaciones, toda vez que lograron superar el contradictorio e irreal dominio sobre el término al fijar estas nuevas cargas forales sobre una parte de la tierra comunal, especialmente la que era objeto de roturación ${ }^{7}$.

Ahora bien, ¿dónde residía la capacidad y dominio territorial ostentado por estos señores jurisdiccionales?. Legalmente sólo puede hallarse en los títulos o mercedes otorgados por los reyes en el momento de constituirse el señorío, títulos y mercedes que, como se verá, fueron cuestionados posteriormente, especialmente aquellos otorgados por Enrique II. En efecto, parece incuestionable que el rey cede a los nuevos señores todo el poder jurisdiccional (jurisdicción civil y criminal, mero y mixto imperio), e incluso determinadas rentas o derechos reales como las alcabalas, yantares, martiniegas, portazgos, etc., pero la cuestión se complica cuando en los títulos y privilegios se hace también referencia a la tierra, términos y territorios, es decir, al dominio territorial sobre un espacio que en no pocas ocasiones está ya repartido entre el estamento

\footnotetext{
${ }^{7}$ El propio artículo $4^{\circ}$ del Decreto de 1811 intenta favorecer a los vasallos y librarles de las rentas que pagan como cargas fijas anuales y que no guardan relación directa con la tierra..
} 
eclesiástico, los propios vasallos y sus respectivas organizaciones concejiles. Esto nos induce a pensar que dicha referencia a los títulos es un mero formulismo que si llegó a tener una aplicación práctica se manifestó sobre determinados espacios vírgenes y recursos colectivos. El hecho de que en la práctica totalidad de los títulos a partir del siglo $\mathrm{XIV}^{8}$ aparezcan estas referencias contradictorias, relativas a un término y a una tierra que está en manos privativas, genera posteriormente una doble situación, incluso en el ámbito de un mismo señorío?: la de aquellos señores que consiguen hacer efectivo, en parte, ese dominio territorial y como tal seguir percibiendo los censos de frutos pagados anteriormente a los reyes; o la de los que amparándose en esos títulos y considerándose administradores en última instancia de la tierra y recursos no privativos ( montes, ríos, pesca, etc.) logran imponer nuevas cargas al obligar a los concejos a firmar contratos forales enfitéuticos sobre las tierras vírgenes roturadas y sobre todos los espacios repartidos por el concejo ( arrotos, heredades, etc). En el primero de los casos el nuevo titular interpreta que el rey junto al poder jurisdiccional también le cede las rentas y censos que percibía en concepto de señor de vasallos y de la tierra y como tal se arroga la titularidad y dominio de esa tierra "sin dueño", mientras que en el segundo caso, al no existir previos deberes de pago, los nuevos señores intentarán imponer su dominio cada vez que la tierra o el término quede sin usufructuarios(despoblados) o cuando los concejos intenten transformar el uso comunal y privatizar el usufructo a través del reparto y de las roturaciones(quiñones, arrotos).

El propio desarrollo del señorío nobiliario en una parte de la provincia leonesa, que hasta esos momentos estaba bajo la jurisdicción realenga o de las instituciones eclesiásticas, y la existencia de anteriores realidades sociales y políticas asentadas durante el reinado de los reyes leoneses en la Alta Edad Media van a imprimir al señorío leonés un

\footnotetext{
${ }^{8}$ En 1369 Enrique II crea el señorío de Oropesa dando a los nuevos señores todos los términos poblados e por poblar, rentas, pechos, derechos... casas, heredades, posesiones hornos, molino...etc. Tanto este como sus sucesores hasta los Reyes Católicos siguen otorgando esas mismas mercedes a la hora de crear los nuevos estados señoriales. Pero, aunque parezca contradictorio, la mencionada cesión de términos, tierras, pastos, etc., no va a afectar a la situación y al pleno dominio ejercido por los vasallos sobre la mayor parte de la tierra. Otra cuestión será, y ahí es donde se planteará la lucha con los concejos, la tierra y los otros recursos y aprovechamientos comunales. Vid. MOXO, S. De. Los señoríos.... Hispania, 1964, no 95, pp. 401-411.

${ }^{9}$ Esto se aprecia en los señoríos leoneses ya que no todos los lugares o concejos dependientes de una misma jurisdicción señorial pagan fueros concejiles o rentas señoriales vinculadas al término o a la tierra. Así, mientras que todos los lugares que forman la Jurisdicción de Villanueva de Jamúz pagaron durante toda la Edad Moderna el fuero malo proveniente del censo de frutos situado sobre el cuarto de la producción de las tierras comunales roturadas, en la Jurisdicción de Benavides dependiente del mismo señor, la mayoría de los concejos no pagan fuero alguno al no existir vínculo censal anterior a la llegada del señorío nobiliario o al oponerse los concejos a reconocer una prestación o renta censal pagada o no anteriormente al rey.
} 
carácter diferencial con respecto al implantado en otros territorios de la Corona de Castilla. Este carácter unificador se aprecia en el peso y elevado porcentaje que suponen las rentas enajenadas, especialmente las alcabalas, en el montante de la renta señorial y de forma especial la escasa participación en la tierra si descontamos las rentas forales emanadas de los contratos enfitéuticos impuestos sobre los términos, algunos bienes comunales y sobre dehesas, cotos o términos procedentes de lugares despoblados. Pese a todo, desde la progresión de un mayor dominio solariego, conforme nos acercamos a las tierras castellanas ( sur-este provincial), hoy se puede afirmar que la propiedad territorial de la nobleza señorial leonesa no superó el 5\% de la tierra productiva, incluso contando aquellos espacios vírgenes considerados bajo los contratos forales concejiles.

Parece claro, pues, que fue la jurisdicción la que abrió las puertas a la nobleza en su intento por ampliar o conseguir algún dominio sobre la tierra y con ella ampliar la capacidad de captación de la renta agraria, una tierra que, dadas las condiciones repobladoras de la provincia leonesa, estaba ya prácticamente repartida a su llegada al poder jurisdiccional. Esto es visto claramente por el fiscal del estado a la hora de intentar desmantelar los planteamientos de la casa Miranda en sus pretensiones de separar la condición solariega, y de forma especial la territorial, de la jurisdiccional, sin que, como veremos, pueda lograrlo pese al resultado final a su favor. Pero, pese a que el poder jurisdiccional parece facilitar, en teoría y especialmente a partir del siglo XIV, el acceso de los señores al territorio, es decir a la tierra, en la práctica los resultados finales van a ser muy desiguales en el conjunto del territorio provincial, toda vez que la práctica totalidad de este territorio, repoblado durante la Alta Edad Media a través de los fueros, estaba ya en manos de pequeños campesinos libres y propietarios organizados en comunidades concejiles de aldea, dotadas de una alta capacidad de autogestión y de un poder político concejil que en ningún caso pudieron suplantar o eliminar los nuevos señores. Estos hubieron de conformarse con aceptar la presencia de ese poder político administrativo autónomo y apoyarse en la capacidad que la jurisdicción le otorgaba para controlar el poder judicial ordinario y a través de él velar por sus intereses. Aquí puede encontrarse una de las razones del porqué en estos territorios del Reino de León, ni las villas, ni las ciudades tienen poder alguno sobre las comunidades concejiles campesinas(lugares) que se sitúan en su entorno o alfoz. De la misma forma los nuevos señores jurisdiccionales tampoco lograron unificar política y 
territorialmente el término de su jurisdicción, dado que cada comunidad mantuvo siempre delimitado el espacio o término sobre el que el concejo y el poder concejil ejercían gobierno, administración y usufructo de la tierra y de los recursos.

Así pues, para entender el desarrollo del régimen señorial en la Corona de Castilla y de forma especial en el Reino de León hay que partir del contexto político bajomedieval en el que se produce el fuerte proceso de señorialización y de las propias estructuras territoriales y sociales existentes, fuertemente arraigadas a la llegada del nuevo poder nobiliario y en buena medida formadas durante el proceso repoblador de la Alta Edad Media. El hecho de que en el siglo XIX se plantee la separación del jurisdiccional con respecto al solariego y territorial, toda vez que las nuevas leyes sólo pretenden suprimir el primero, tenía como primer objetivo respetar la realidad existente en el seno del estamento nobiliario señorial y su relación con la tipología de sus rentas, realidad conservada durante toda la Edad Moderna y a la que se había llegado bien a través de aprovecharse y extralimitar sus derechos como poder jurisdiccional ante la pasividad de la Corona y de la justicia real, bien mediante la imposición, coacción e incluso pacto con las comunidades concejiles campesinas. La etapa fundamental para entender este proceso se sitúa en los siglos XIV y XV y, si bien los Reyes Católicos parecen poner freno a partir de la última década del siglo XV, la situación en el caso del señorío que nos ocupa se va a mantener hasta la década de los años treinta del siglo XVI, como consecuencia de la inestabilidad política de los primeros años y del triunfo "arrogante " de los señores fieles a Carlos V una vez que caen derrotados los comuneros. No es casual que sea por estas fechas cuando por última vez esta nobleza señorial llegue a un acuerdo o imposición con los concejos para elevar a escritura pública unos contratos denominados fueros (foros enfitéuticos) por los que se les reconocía el derecho a percibir una renta en especie y con ella el dominio directo sobre el término, sobre los recursos no privativos y sobre los espacios comunales roturados y repartidos en quiñones por el concejo. La paradoja, como veremos, surge cuando conocemos que la tierra o espacio que forma el delimitado término de cada comunidad era privativo de los campesinos, del concejo o de otros grupos privilegiados. Pero, en este proceso, en el que la nobleza intenta trasladar derechos eminentemente señoriales o vasalláticos a la tierra, los resultados finales y los logros son muy desiguales, dependiendo estos de la capacidad de respuesta de las comunidades concejiles y sobre todo de las condiciones pactadas con los 
reyes en el momento de la repoblación o de la concesión de los fueros y cartas repobladoras. De la misma forma que los nuevos señores dieron por supuesto, con la complacencia de los monarcas trastámara, que junto al poder jurisdiccional se le cedía el derecho a percibir otras rentas como las alcabalas, hacen suyo el derecho a percibir las otras rentas o censos de frutos (quinto o cuarto) que las comunidades habían pactado con los reyes a la hora de cederles, mediante cartas puebla o fueros, la propiedad y usufructo de la tierra privativa y de la comunal. Ello explica que, frente a ejemplos localizados principalmente en algunas jurisdicciones del Conde de Luna, existan dominios o estados señoriales en los que solamente una parte de las comunidades mantienen este tipo de rentas o censos de frutos transformados en fueros o foros enfitéuticos pagados por el concejo o por la comunidad ${ }^{10}$.

La vinculación que los concejos hacen durante toda la Edad Moderna de determinados deberes de pago de carácter eminentemente señorial, como las martiniegas, yantares, etc., dan a entender que las comunidades eran conscientes del origen y naturaleza de dichas rentas y en modo alguno parecen cuestionarlas, bien porque los señores ya habían ganado sentencias favorables, bien porque eran conscientes de que sus antepasados habían firmado contratos forales por los que se le cedía a la comunidad el dominio útil y usufructo a cambio de una renta y condiciones muy ventajosas. Salvo excepciones puntuales de largos litigios cerrados y abiertos durante toda la Edad Moderna, como los entablados por algunos concejos mayores leoneses contra el conde de Luna por la titularidad de los puertos de merinas, en conjunto se puede afirmar que las comunidades no cuestionaron estos contratos hasta finales del siglo XVIII cuando algunos señores, conscientes del final del régimen señorial, comienzan a exigir el reconocimiento territorial y solariego para garantizar unas rentas que habían percibido desde la Edad Media. Se trataba de situar estos derechos a través de contratos mercantiles y del reconocimiento de la plena propiedad. Pero he aquí que las condiciones van a cambiar cuando a partir de las primeras décadas del siglo XIX, desde el soporte legal de la legislación de cortes que regulaba la abolición de los señoríos, el Estado empieza a reclamar la enajenación e in-

\footnotetext{
${ }^{10}$ La referencia en la documentación a fueros en lugar de foros se debe a que los citados contratos, que generalmente tienen carácter concejil, además de estar normalmente vinculados a rentas señoriales como las martiniegas o yantares, sustituyen a los viejos censos de frutos, cuartos o quintos, de ahí la denominación que reciben de fueros malos. Estos fueros son pagados por los concejos comunalmente a cambio del usufructo de determinados espacios no privativos, de nuevos espacios roturados o en el peor de los casos como reconocimiento del dominio sobre el término concejil.
} 
corporación de parte de esa tierra cuya titularidad era difícil o imposible de demostrar por parte de los señores a través de contratos puramente mercantiles de particular a particular. No sólo carecían de títulos de compra y propiedad, sino que la propia documentación aportada, generalmente privilegios y mercedes enriqueñas, demostraban su total vinculación al jurisdiccional abolido.

En esta tesitura y a partir de la década de los años treinta del siglo XIX la situación va a cambiar y la posibilidad de modificar las relaciones y dominios sobre los términos y la tierra y espacios comunales, caso de ser enajenadas por el Estado, parece justificar, como veremos, el pacto y la convergencia de intereses de los señores y algunas comunidades concejiles, e incluso los propios campesinos a título particular conscientes de que su situación y los contratos iban a modificarse en claro perjuicio para ellos. La actitud detectada tanto en las comunidades leonesas, como en otras situadas incluso en la Corona de Aragón, a la hora de testificar a favor de los señores para que el estado liberal le reconociese el territorial sólo puede entenderse desde la pretensión de aquellas de que las relaciones y contratos forales se mantuvieran como lo habían estado durante siglos. Además, las comunidades campesinas, conscientes y conocedoras de la actitud de los posibles nuevos propietarios burgueses, parecen preferir las relaciones con señores en cierto modo alejados físicamente de sus comunidades. ${ }^{11}$

\section{El estado señorial de Palacios e Infantazgo de Valduerna: los Viz- condes de Bazán y el origen del dominio.}

El linaje de los Bazán tiene sus raíces en el valle navarro del Baztán de donde toman el apellido y en donde inicia el linaje su andadura en 1135 al servicio del rey García Ramirez. En 1283 una rama de esta nobleza navarra encabezada por Juan González de Baztán pasa al servicio de los reyes de Castilla, siendo su hijo García González de Baztán, casado con la leonesa Aldonza García de Villamayor, quien se asienta en tierras de Astorga al amparo de las concesiones del rey Sancho IV y de

\footnotetext{
${ }^{11}$ Esta actitud y problemática, que afecta a muchos señoríos leoneses se aprecia también en territorios del Reino de Galicia y de Valencia. Vid: P. RUIZ TORRES. Señores y propietarios. Cambio social en el sur del País Valenciano, 1650-1850. Valencia, 1981. P. SAAVEDRA.Contribución al estudio del régimen señorial gallego, en Anuario de Historia del Derecho Español. LIX,1990, pp. 108-112. Del mismo autor: Régimen señorial y administración local en la Galicia de los siglos XVI-XVIII. Separata de Historia da administración. Escola Galega de Administración Pública., pp. 29-62 ; Señoríos y comunidades campesinas en la España del Antiguo Régimen, en Señorío y Feudalismo en la Península Ibérica, ss. XII-XIX. Zaragoza, 1993. Pp.427-474.
} 
la herencia del Arcediano de Santiago. ${ }^{12}$ La posición económica y social alcanzada en Astorga por Juan González Baztán (Bazán), hijo mayor de los anteriores, y el apoyo ofrecido a Enrique II en la guerra, hacen que sea este rey quien, en consonancia con su débil posición y en el contexto de una oscura política de mercedes, le conceda en 1366 el señorío que en torno a la villa de Palacios del Rey se va a asentar en las tierras del Infantazgo de Valduerna que hasta ese momento habían estado bajo el dominio realengo ${ }^{13}$. Aunque no se trata de una nobleza "nueva" o recién llegada, dada su posición social anterior tanto en Navarra, como en Castilla, la formación del dominio señorial a través de la mera cesión y enajenación de estos territorios realengos en unos momentos de crisis política, social y económica, estuvo desde un principio condicionada por la presencia de unas comunidades campesinas plenamente organizadas en torno al poder concejil, a un alto nivel de autogestión basado en el Derecho Consuetudinario y en un marco legal que, emanado de los fueros repobladores y de las viejas leyes visigóticas, les permitió hacerse con la mayor parte de los medios y de la tierra que forman el espacio o término sobre el que se asientan, usufructúan y administran. Sobre estas bases los nuevos señores, que habían recibido del rey la jurisdicción civil y criminal, mero e mixto imperio por los buenos e leales servicios...,difícilmente podían desarrollar el dominio solariego al que accedieron durante esa crítica fase otros linajes castellanos ${ }^{14}$. Pese a que el nuevo linaje poseía ya un patrimonio raíz en las tierras cercanas a Astorga, las limitaciones a la hora de extenderlo por la vía del nuevo poder jurisdiccional eran muchas, máxime cuando la mayor parte de la tierra estaba ya repartida entre el clero, los campesinos y las comunidades concejiles.

Ahora bien, en el documento de donación y creación del señorío en 1366 no se hace referencia explícita a los derechos cedidos, sino simplemente se afirma que la donación de la villa y el Infantazgo de Valduerna se ceden en las mismas condiciones y derechos que los había po-

\footnotetext{
${ }^{12}$ SOTES,A. El convento de S. Francisco de Astorga. Astorga, 1934.

i3 Se trata de un dominio que engloba a 35 lugares o comunidades concejiles de aldea entre los que se encuentran las villas de Palacios, sede del poder jurisdiccional, y La Bañeza, situado en la zona sur de la provincia leonesa y en las tierras que se asientan entre la citada villa y Astorga. Tanto en el siglo XVI como en el XVIII la cifra de vasallos vecinos cabezas de casa que estuvieron bajo dominio jurisdiccional estuvo en torno a los mil quinientos. Vid al respecto: RUBIO PEREZ,L: El señorío leonés de los Bazán: aproximación a su realidad socioeconómica, 1450-1650. León, 1984.

${ }^{14}$ ESTEPA,C. "Propiedad y señorío en Castilla, siglos XIII-XIV", en Señorío y Feudalismo en la Península Ibérica, t.I, Zaragoza, 1994, pp. 424-425.
} 
seído Dña. María de Benavides ${ }^{15}$. Sin embargo, posteriormente con la creación del vizcondado en la persona de Pedro de Bazán a mediados del siglo XV las confirmaciones, en especial las expedidas por los Reyes Católicos, se menciona expresamente la donación de la villa de Palacios e Infantazgo de Valduerna con sus vasallos e dezmerías e territorios, e terminos e con los montes, ríos e fontes e con la jurisdicción civil e criminal alta e baxa e con el mero e mixto imperio... ${ }^{16}$. Aunque queda clara la cesión del poder jurisdiccional y en la misma línea la del traslado y enajenación de rentas reales como diezmos, tercias y alcabalas, la cuestión empieza a complicarse a la hora de valorar los otros componentes, en especial los referidos a territorios, términos y otros recursos económicos existentes en ellos. El hecho de que ya en 1461 el primer vizconde Pedro de Bazán venda al concejo de La Bañeza, bajo su jurisdicción, la propiedad del reguero Fontorio por el que se abastecía de agua la villa ${ }^{17}$ viene a demostrar que los nuevos señores ya se consideraban dueños y administradores de los recursos no privativos, especialmente del agua y los demás recursos de los cauces fluviales. Este dominio, supuestamente adquirido desde la legalidad del poder jurisdiccional, pero en la práctica usurpado a los concejos durante la crisis bajomedieval, queda nuevamente puesto de manifiesto cuando el señor de Palacios cede un pedazo de monte al señor de Destriana, villa ésta rodeada por su territorio jurisdiccional y perteneciente a la Orden de Santiago, a cambio de la concesión y permiso para construir una presa y abrir un cauce denominado rauda por el que conducir el agua a la villa de Palacios y a los campos de una parte de los pueblos situados en su entorno. El posterior levantamiento de molinos en este cauce, todos ellos foreros hasta el siglo XIX de la casa señorial, viene a confirmar el incuestionado dominio que estos señores mantuvieron durante la Edad Moderna de la mayor parte de los recursos hídricos. Pero, este dominio adquirido fácilmente a partir del poder jurisdiccional no va a alcanzar las mismas dimensiones cuando se trata de la tierra y de forma especial de aquellos espacios mencionados por el documento fundacional referidos a los montes y tierras no privativas ${ }^{18}$. Estos, a diferencia de los recursos hídricos, estaban situados dentro de

\footnotetext{
${ }^{15}$ Archivo Municipal de Palacios. Documentos. Real Carta Ejecutoria.

${ }^{16}$ A.G.S., R.G.S., fol.74, Toledo, 1477.

${ }^{17}$ Este documento es recogido por SEGOVIA, J.M. Algunas efemérides bañezanas, pp.11-15.

18 En el pleito suscitado en el siglo XIX la parte que representa a la casa insiste constantemente en hacer referencia a su señor como señor territorial de la Valduerna. Esto se aprecia en el interrogatorio al que se someten algunos vasallos que testifican a favor de los intereses señoriales al responder positivamente a la pregunta $4^{\mathrm{a}}$ en la que se les pregunta si es cierto que cualquier vecino de la Valduerna que quiere poner molino en la rauda ha tenido que pedir licencia al señor como señor territorial de la misma y de su exclusiva propiedad aforándole el sitio que ocupa aquel artefacto. A.M.P. Real Carta Ejecutoria, fol.401.
} 
cada término concejil y eran parte de un patrimonio comunal recogido por los fueros y cartas fundacionales y administrado por cada uno de los concejos o comunidades concejiles. Pese a los intentos y pese a las referencias documentales, los señores de Palacios sólo consiguen privatizar una mínima parte de las más de diez mil Has. de montes de su territorio jurisdiccional ante la posición de unos concejos que administraban ya plenamente los terrenos comunales de su término concejil ${ }^{19}$. La oposición concejil a estas pretensiones señoriales aparece ya a finales del siglo XIV cuando el señor de la casa, Juan González Bazán, en una clara estrategia de conseguir el dominio a través de la forma indirecta de los reconocimientos concede permiso a los vecinos de su villa de Palacios para cazar, pescar e cortar leña en todos los ríos e montes de su jurisdicción ${ }^{20}$. La consumación de este acto hubiera supuesto el reconocimiento, de facto, de un dominio y la culminación de la única estrategia posible para ampliar el reducido patrimonio territorial de la casa. Pero, la frontal oposición de los concejos y de forma especial del concejo de Tabuyo del Monte, que mantuvo largos pleitos judiciales con la villa de Palacios, frenaron la posible vía de acceso al control de unos espacios comunales $\mathrm{y}$, en cierto modo, la pretendida creación de un territorio o dominio señorial que más allá del dominio jurisdiccional suprimiera la arraigada división territorial en torno a los diferentes términos concejiles, cuya titularidad y usufructo había sido reconocido durante la Alta Edad Media a cada una de las comunidades de aldea, incluso a la propia villa cabeza de la nueva jurisdicción $^{21}$.

Parece claro, pues, que en el siglo XVI la práctica totalidad de las comunidades de aldea o lugares que componen el dominio jurisdiccional de los Bazán tienen ya reconocido el control, dominio y la administración de su propio término, tal como le había sido reconocido en los fueros o cartas fundacionales por parte de los reyes de León. Pero, el problema surge cuando posteriormente la monarquía cede estos territorios y sus vasallos a la nueva nobleza y ésta se llama a los beneficios, prestaciones y contratos que esos vasallos habían pactado con la corona, espe-

\footnotetext{
${ }^{19}$ La casa señorial solamente consigue adueñarse en el siglo XV de cuatro pedazos de monte situados en los lugares de Fresno, Robledino, Villalís, Castrillo y Torneros con una superficie total inferior a las quinientas Has.

${ }^{20}$ A.M.P. Pergamino, $\mathrm{n}^{\circ} 1$. "Otorgo por esta mi carta e por fazer bien e merzed al concejo e vezinos de mi villa de Palacios que pescades, cazades e cortades leña de cualquier forma en toda la tierra de Palacios e su jurisdicción...".

${ }^{21}$ Entre 1535 y 1545 la villa de Palacios mantiene largos pleitos con los concejos de Tabuyo y Priaranza en relación a la defensa que estos concejos hacen de los recursos forestales existentes en sus términos. A.M.P. doc. 19-31.
} 
cialmente a la hora de administrar y usufructuar los recursos no privativos existentes en el término jurisdiccional. Pero, $i$ la cesión regia por la que se creaba el señorío incluía, amén del poder jurisdiccional, a los recursos y bienes no privativos controlados por los respectivos concejos y delimitados en sus correspondientes términos?. A juicio de los nuevos señores parece ser que sí y de hecho hasta finales del siglo XV lograron que todos los concejos, que de alguna forma habían mantenido durante la Alta Edad Media prestaciones y rentas con la Corona, se las trasladaran a ellos. La situación empieza a complicarse en el siglo XV cuando los vasallos comienzan a cuestionar viejas prestaciones señoriales que habían ofrecido a los reyes ${ }^{22}$ y cuando la mayor parte de las comunidades logran frenar los intentos señoriales de hacerse con el dominio de unos espacios y recursos incluidos y perfectamente delimitados dentro de cada término concejil . Posteriormente, la mayor garantía judicial impuesta por los Reyes Católicos, la recuperación económica y demográfica y el fortalecimiento de las propias comunidades concejiles se presentan, a finales del siglo XV y principios del XVI, como importantes factores a la hora de frenar las pretensiones señoriales de consolidar y aumentar el patrimonio territorial y solariego más allá de lo pactado hasta esos momentos con una parte de esas comunidades.

Sin embargo, aunque el dominio solariego y las prestaciones vasalláticas vía rentas de frutos no se van a poder incrementar ni modificar, la revolución de las Comunidades y la posterior victoria de los señores de Bazán al lado de las tropas reales de Carlos $\mathrm{V}$ propiciaron a éstos la ocasión para imponer a vasallos particulares y a los concejos con los que mantienen vínculos, prestaciones o censos de frutos por el usufructo de espacios y recursos comunales, nuevas formas y reconocimientos que, a la postre, iban a acercarle más a la plena propiedad. En efecto, los señores fortalecidos por el triunfo realista parecen obligar a vasallos y comunidades a reconocer ante el notario público de la villa el dominio territorial y los derechos mediante las correspondientes escrituras de foros enfitéuticos, lo que de hecho suponía un importante cambio con respecto a la forma de posesión anterior ya que ese reconocimiento foral legitimaba la plena propiedad y el carácter mercantil de los nuevos contratos. Como se verá posteriormente, el apoyo jurídico y legal esgrimido en el siglo XIX por la casa en su pretensión de que se le reconozca y respete el solariego y territorial se basará en estos contratos

\footnotetext{
${ }^{22}$ En 1454 son los lugares de sobrecalzada y el de La Bañeza quienes se niegan a acudir a reparar la torre del castillo y el muro de la cerca de la villa, lo que supone el primer conflicto judicial entre el señor y sus vasallos. A.M.P. Pergamino $\mathrm{n}^{\circ} 4$.
} 
solariego y territorial se basará en estos contratos forales firmados en $1534^{23}$.

\section{Dominio solariego, dominio territorial: origen, implantación y ti- pología.}

El linaje de los Bazán accede a su condición de señores de vasallos a raíz de una concesión regia y sin que ello supusiera la existencia de otro tipo de dominios que los meramente jurisdiccionales en tanto en cuanto, como vimos, la mayor parte del patrimonio familiar heredado se asentaba en el entorno de la ciudad de Astorga. Recibía, pues, esta influyente familia la capacidad de impartir poder político y judicial en un extenso territorio y sobre un total de treinta y cinco comunidades concejiles de aldea mayoritariamente asentadas en torno al Infantazgo de Valduerna y en un área geográfica que va desde las vegas del Orbigo hasta las tierras montañosas de la Maragatería donde se asientan comunidades como Rabanal del Camino, Viforcos o Santiagomillas. En su conjunto se trata de pequeñas e independientes comunidades campesinas, perfectamente organizadas en torno al poder concejil y al Derecho Consuetudinario emanado de las cartas o fueros fundacionales, y la mayor parte de ellas formadas y consolidadas durante el fuerte proceso repoblador de estas tierras llevado a cabo bajo la tutela de los reyes de León y de los cenobios entre los siglos X y XIII. Este proceso no sólo hizo que se triplicara el número de comunidades con respecto a las ya existentes desde su origen romano o visigótico, sino que fragmentó el territorio en un número de términos similar al de comunidades, ya que cada una de ellas pasó a poseer su propio territorio o término, así como la propia administración de éste.

En este contexto y desde estas bases de partida el nuevo dominio señorial creado por los Bazán se hallaba condicionado no sólo por la propia distribución social del espacio, de los recursos y de la propia tierra, sino incluso por la presencia de un poder local concejil sobre el que no logró imponerse el nuevo poder señorial fuera del marco eminentemente judicial. Ni en la Baja Edad Media, ni durante la Edad Moderna, el poder señorial logró someter y mucho menos eliminar al poder local que cada comunidad poseía y ejercía a partir de un gobierno concejil, elegido anualmente al margen de cualquier intervención señorial, que además de contar con su

\footnotetext{
23 Archivo Histórico Provincial de León(A.H.P.L.). Protocolos, caja 6843. En 1534 y ante el notario de la villa de Palacios Francisco Nieto vasallos y concejos bajo la Jurisdicción de los Bazán reconocen los derechos, dominios y propiedades de los señores mediante las correspondientes escrituras de foros enfitéuticos en las que se establece el tipo de dominio o bien y las correspondientes rentas forales a pagar.
} 
propia justicia pedánea tenía su propio marco legal en el ordenamiento concejil o Derecho Consuetudinario. A partir de estas consideraciones, que se nos presentan como básicas para entender el proceso del régimen señorial en el Reino de León y su carácter diferencial del resto de territorios de la corona castellana, se pueden entender algunas de las limitaciones del poder de los señores ya que pese a poseer el control y la administración de la justicia ordinaria sobre el conjunto de comunidades y vasallos y la capacidad de supervisión de la justicia pedánea no lograron desarrollar su poder político más allá de la influencia supervisora ejercida sobre el gobierno concejil electo en la villa cabeza de jurisdicción ${ }^{24}$.

A partir de estas limitaciones y de las propias estructuras existentes con anterioridad, los nuevos señores jurisdiccionales tenían limitada su capacidad de actuación a la hora de asentar su dominio territorial sobre un espacio que en la práctica ya estaba ya estaba repartido, delimitado y administrado por cada una de las comunidades concejiles y por las múltiples instituciones eclesiásticas seculares y regulares que poseen ya más del $50 \%$ de la tierra labradía. A este alto porcentaje hay que unir otro $40 \%$ de superficie productiva virgen y labradía privativa de los campesinos y administrada, caso de las praderías y montes, por cada concejo bajo el régimen comunal. Partiendo de esta distribución social del medio tierra, consolidada ya con anterioridad al señorío, las posibilidades de desarrollo de un dominio solariego y territorial estaban muy limitadas y solamente podían presentarse durante la crisis bajomedieval y desde la presión ejercida sobre esa parte cualitativamente importante de tierra roturada o virgen comunal administrada por los concejos o repartida por la comunidad desde antiguos compromisos de pago de censos de frutos (cuarto o quinto) a los reyes y a otros antiguos señores repobladores.

Pero, pese a estos condicionantes estructurales de partida, parece claro que la actitud de esta nobleza fue la de asentar y consolidar un dominio territorial a partir del poder y de la capacidad que le otorgaba el poder jurisdiccional y de la interpretación de unos títulos y mercedes que

\footnotetext{
${ }^{24}$ Este aspecto constatado en la práctica totalidad de los señoríos leoneses justifica la presencia hegemónica de los gobiernos concejiles elegidos anualmente sin intervención del poder jurisdiccional que se limita a velar por el cumplimiento del Derecho Consuetudinario y a entender en causas de apelación de las justicias pedáneas concejiles. La presencia y conservación del Real Adelantamiento de León desde la Alta Edad Media hasta el siglo XIX como tribunal regio, ordinario y de apelación de las sentencias dictadas por las justicias ordinarias señoriales antes de la vía extraordinaria de la Real Chancillería de Valladolid parece estar justificada en esta situación y realidad estructural conocida por los Reyes Católicos en el momento de decidir mantener dicha institución judicial en la Provincia leonesa.

Al respecto vid. RUBIO PEREZ, L.M. El sistema politico concejil en la provincia de León durante la Edad Moderna. Universidad de León, León, 1993.
} 
les otorgaban la administración de la tierra y de los recursos no privativos existentes en el territorio señorial. A finales del siglo XV las contestaciones concejiles, la negativa a determinadas prestaciones feudales y la propia coyuntura económica parecen convencer a esta nobleza de la necesidad de acceder a las rentas agrarias mediante la nueva vía de la tierra y del reconocimiento del dominio directo de aquellos medios vinculados a ella. Conscientes de la nueva situación los Bazán consiguen adueñarse de un patrimonio y de unas rentas que si bien, como veremos, no alcanzan los porcentajes de otros linajes, les permiten unos importantes ingresos anuales y lo que es más importante, la formación de un dominio territorial y solariego que completaba la cuantía de recursos y rentas provenientes de rentas cedidas y enajenadas como las alcabalas.

En efecto, en primer lugar hay que destacar que el dominio territorial y solariego que posee la casa a principios del siglo XVI y que posteriormente pretende se le reconozca en el siglo XIX se halla muy repartido entre veintisiete de los treinta y cinco lugares o concejos bajo su jurisdicción, pues en ocho de estos la casa sólo posee derechos sobre las alcabalas. Tan sólo en cinco lugares que no pertenecen al señorío declaran los señores posesiones, siendo en las villas de Palacios y La Bañeza donde se halla el mayor peso del dominio solariego a través de las denominadas heredades y de los fueros impuestos a las casas, lo que viene a demostrar que la presencia de los señores en la Baja Edad Media y posteriormente de sus representantes directos en estas villas es un factor a tener en cuenta a la hora de ejercer una mayor presión que en el resto de los lugares o comunidades que forman el señorío ${ }^{25}$. En conjunto y desde las dificultades que encierra una valoración global, al no coincidir la división administrativa actual con la jurisdiccional señorial, se puede decir que el territorio señorial se extendía sobre una superficie aproximada de $350 \mathrm{Km} 2$ que incluye una superficie productiva algo superior a las 35.000 Has. distribuidas en un $49 \%$ en tierras labradías; en un $28 \%$ en monte y en un $23 \%$ en prados y pradería.

\footnotetext{
25 En la villa de Palacios posee la casa cuatro heredades de tierra labradía compuestas por unas doscientas fanegas, mientras que en La Bañeza la tierra labradía también, repartida en heredades foreras alcanza las 300 fanegas. El hecho de que la mayor parte de estas heredades tengan sobre sí fueros o foros concejiles o colectivos viene a demostrar que su formación surgió a partir de las roturaciones dirigidas por los concejos con el posterior reparto de quiñones o lotes entre los vecinos que no sólo los usufructúan de por vida, sino que los dejan en herencia a sus descendientes (heredad). Este proceso conllevó el compromiso de pago por parte de la comunidad de una parte de los frutos (censo) que posteriormente, como ya apuntamos, se convirtió en un contrato foral denominado fuero enfitéutico.
} 
Desde estos valores y con los datos de la propia casa no sólo podemos conocer el peso del dominio solariego señorial en el conjunto territorial, sino algo tan importante como la distribución y tipología de dicho dominio. Este aspecto nos permite, a su vez, conocer el origen y la forma de adquisición de ese dominio solariego. En efecto, el dominio solariego y territorial de los señores apenas se modificó a lo largo de la Edad Moderna y pese a perderse algunas heredades, como ellos mismos reconocen, y haber vendido a principios del siglo XVIII el despoblado de Hinojo a la familia Castañón de La Bañeza, a principios del siglo XIX el dominio solariego se extendía sobre unas 1250 Has. de tierra de las cuales el $19 \%$ corresponde a tierra labradía aforada y arrendada a particulares; el $51 \%$ a tierra vinculada a los fueros concejiles y el $30 \%$ a montes $^{26}$. Esta propiedad, muy repartida entre los 27 lugares de la jurisdicción, supone tan sólo un 3,5\% sobre el total de la tierra productiva, porcentaje que apenas se incrementa si consideramos solamente la tierra labradía. A su vez, las cifras ofrecidas por una muestra compuesta por once lugares a partir de las valoraciones o Resúmenes Generales del Catastro de 1752 vienen a confirmar los porcentajes anteriores y solamente se aprecia un ligero incremento hasta el 5,5\% en relación a la tierra labradía. Parece claro, pues, que el dominio solariego y territorial de estos señores en relación a la superficie total del territorio es más bien reducido y ello se debe fundamentalmente a las razones apuntadas anteriormente ${ }^{27}$.

Ahora bien, uno de los aspectos a destacar en las pretensiones de los señores de que el Estado le reconozca el señorío solariego y territorial y en el que parece poner más énfasis el ministerio fiscal fue la tipología y el origen de este dominio, toda vez que los señores carecían de otro título que no fuesen las mercedes y privilegios hechos por los reyes trastámara al cederles la jurisdicción. Los valores de la tabla obtenida de la propia documentación presentada por la casa ante la justicia ofrecen alguna luz al respecto y nos permiten conocer la forma de acceso al dominio y el peso de las correspondientes rentas forales dada la escasa importancia del contrato a corto plazo o arriendo.

\footnotetext{
${ }^{26}$ Se le reconocen a los Bazán por parte de los concejos la posesión de cinco pedazos de monte encina que ocupan una extensión de unas 375 Has. y se hallan situados en término de los concejos de Robledino, Fresno, Villalís, Castrillo y Torneros.

${ }^{27}$ En el conjunto de las Tierras Bañezanas, sometidas a un fuerte proceso de señorialización durante la Baja Edad Media por parte de la nueva nobleza señorial leonesa (Conde de Luna, Marqués de Astorga, Conde de Benavente), etc. , el dominio nobiliario sobre la tierra labradía se sitúa en el $7 \%$, frente al $46 \%$ de la propiedad campesina y el 44\% del estamento eclesiástico. Vid. RUBIO PEREZ,L.M. La Bañeza y su Tierra, 16501850. Biblioteca de Castilla y León : Universidad de León, 1987, pág.221.
} 
Estructura y tipología del dominio solariego y territorial del Conde de Miranda en su Estado de Palacios e Infantazgo de Valduerna según su procedencia y rentas generadas.

\begin{tabular}{|l|l|l|l|l|l|l|}
\hline $\begin{array}{l}\text { Tipo de bien } \\
\text { Procedencia }\end{array}$ & $\begin{array}{l}\mathrm{N}^{\mathrm{o}} \\
\text { dadas } \\
\text { a foro }\end{array}$ & $\begin{array}{l}\mathrm{N}^{\mathrm{o}} \\
\text { dadas } \\
\text { en } \\
\text { arrien } \\
\text { do }\end{array}$ & $\begin{array}{l}\text { Rentas } \\
\text { forales. } \\
\text { Fanegas } \\
\text { de gra- } \\
\text { no. }\end{array}$ & $\begin{array}{l}\text { Rentas } \\
\text { forales } \\
\text { en re- } \\
\text { ales }\end{array}$ & $\begin{array}{l}\text { Rentas de } \\
\text { arriendos. } \\
\text { Fanegas de } \\
\text { grano }\end{array}$ & $\begin{array}{l}\text { Rentas de } \\
\text { arriendos } \\
\text { en reales. }\end{array}$ \\
\hline Casas(1) & 66 & 3 & 30 & 210 & 0 & 220 \\
\hline $\begin{array}{l}\text { Tierras y huertas } \\
\text { entregadas a } \\
\text { particulares }\end{array}$ & 155 & 5 & 68 & 0 & $\mathrm{O}$ & 940 \\
\hline $\begin{array}{l}\text { Heredades de } \\
\text { tierras y arrotos } \\
\text { entregados a } \\
\text { particulares. }\end{array}$ & 16 & 6 & 111,5 & & 211 & 0 \\
\hline Molinos de & 16 & 0 & 544 & & 0 & 0 \\
\hline $\begin{array}{l}\text { Heredades } \\
\text { arrotos o quiño- } \\
\text { nes concejiles. }\end{array}$ & & 0 & 36,5 & & 0 & 0 \\
\hline Despoblados(1) & 1 & 0 & 29,5 & & 0 & 0 \\
\hline Huerta concejil & 1 & 0 & 16 & & 0 & 0 \\
\hline $\begin{array}{l}\text { Pedazos de mon- } \\
\text { te }\end{array}$ & 5 & 0 & & & 0 & 1100 \\
\hline TOTAL & & & $\begin{array}{l}835,5 \\
\text { fanegas }\end{array}$ & $\begin{array}{l}222 \\
\text { reales }\end{array}$ & 211 fanegas & $\begin{array}{l}2260 \quad \text { re- } \\
\text { ales }\end{array}$ \\
\hline
\end{tabular}

(1) Estas cargas forales no hacen referencia a la titularidad de la casa, sino al gravamen impuesto por el señor en el momento de construirla por parte de los vasallos. Se sitúan principalmente en la villa cabeza de jurisdicción. Tampoco se incluye el despoblado de Hinojo vendido por la casa a principios del siglo XVIII a los Castañón.

La relación ofrecida por la tabla nos pone de manifiesto que la mayor parte del dominio solariego no sólo se vincula mayoritariamente a través de contratos forales enfitéuticos, sino que la mayor parte de la tierra se mantiene bajo la denominación de heredades, cada una de las cuales puede superar las 50 fanegas de tierra ${ }^{28}$. Esta denominación o categoría , especialmente en el caso de las 16 heredades de arrotos concejiles

${ }^{28}$ Las seis heredades arrendadas a vecinos particulares suponen un total de 247,5 fanegas de tierra labradía . 
controladas por los correspondientes concejos ${ }^{29}$, acapara la mayor parte de la tierra bajo dominio señorial, lo que vincula, sin duda, dicho dominio a la mayor o menor capacidad de coacción e imposición de los señores sobre los concejos durante la Baja Edad Media, bien por estar plenamente constituida la comunidad concejil y su término con anterioridad a la repoblación, bien por no haber estado sometidos a deberes de pago o censos de frutos vinculados al usufructo de la tierra y de los recursos colectivos . Por el contrario, la presencia de estos contratos forales concejiles o de carácter colectivo o comunitario viene a indicar que el señor consiguió trasladar su dominio jurisdiccional sobre un término concejil que pese a estar ya delimitado y adscrito a cada comunidad concejil poseía una serie de recursos(agua, pesca) y una parte de la tierra no roturada cuya administración y control le correspondía por el mero derecho consignado en los títulos fundacionales. Estos títulos, cuya redacción y contenido es igual para todas las donaciones señoriales por parte de la Corona y que no son cuestionados en relación al poder jurisdiccional transferido, parecen entrar en colisión cuando intentan desarrollarse en el marco de comunidades concejiles plenamente constituidas como las del Reino de León. El objetivo, pues, de los señores era situar ese supuesto poder o dominio sobre el término, es decir, sobre los recursos que se encuentran en él y sobre la tierra no privativa, comunal o concejil. En el caso de los recursos como la pesca o el agua no parece haber problema dado que la práctica totalidad de los molinos existentes de propiedad campesina o concejil pagan forales al señor ${ }^{30}$. La cuestión se complica cuando el señor

\footnotetext{
${ }^{29}$ Es de destacar que tan sólo 16 de los 35 lugares o concejos que forman la Jurisdicción mantienen contratos forales de este tipo con los señores. Dichos contratos, por los que se reconoce el dominio directo señorial, fueron impuestos, como su nombre indica (arrotos), a partir de la roturación de espacios vírgenes y de la correspondiente autorización de unos señores que se arrogaban el dominio y la administración del término de cada concejo y con él de los espacios y recursos no privativos. ¿ Porqué no se llevó a cabo esta situación en el resto de los lugares del señorío?. Parece claro que la oposición concejil y la no existencia previa de estas dependencias y deberes de pago o censos de frutos con los reyes o anteriores señores explican la situación diferencial y la inexistencia de los denominados fueros concejiles.

${ }^{30}$ Este dominio nunca cuestionado por los vasallos y concejos y que se aprecia en los foros impuestos a los molinos privados que se alzan sobre los cauces fluviales queda recogido en la denominada Rauda. Se trata de una presa levantada sobre el río Duerna y su correspondiente cauce o Rauda que conduce el agua durante varios Kms. hacia la villa de Palacios . En el siglo XIX los señores, apoyándose en la declaración de la unanimidad de los testigos presentados, pretenden demostrar su propiedad a partir de un acuerdo que en el siglo XV llevan a cabo con el señor comendador de Destriana para conducir el agua desde término de esta villa a cambio de compensaciones. Pero, dado que el cauce había de transcurrir por término de diferentes concejos (Robledino, Robledo, Fresno y Castrotierra) el señor llega a un acuerdo con los citados concejos para que puedan regar un día de la semana a cambio de reconocerle la titularidad de la obra y los consiguientes contratos forales pagados por cada concejo o vecino que levantase molino a lo largo del cauce. En el posterior pleito con el estado por el reconocimiento del dominio territorial la casa señorial utilizará este dominio sobre los recursos hídricos para conseguir sus objetivos, pese a que se desconoce realmente las condiciones y la legitimidad mercantil de una propiedad que como el resto tiene, a juicio del fiscal, un origen puramente jurisdiccional.
} 
pretende, a partir del poder jurisdiccional que posee, trasladar unos derechos señoriales o vasalláticos, como las martiniegas o los yantares, a toda la tierra o a parte de ella incluida en el término ${ }^{31}$.

En efecto, el hecho de que el Conde de Miranda reclame el reconocimiento del solariego y territorial una vez suprimido el jurisdiccional tiene su razón de ser y los motivos quedan perfectamente reflejados en la tabla anterior, dado que la mayor parte de los forales cobrados se sitúan sobre heredades o extensas propiedades colectivas surgidas de la roturación y reparto de espacios vírgenes. Mientras que en un primer momento las comunidades parecen pagar una serie de censos denominados cuartos o quintos, la propia situación coyuntural y la necesidad de garantizar la titularidad por parte del señor motivó la firma y el reconocimiento de un nuevo contrato foral entre el señor y los concejos denominado fuero y justificado en no pocas ocasiones a partir de contribuciones como las martiniegas (fuero de las martiniegas). En esta misma situación se encuentran los cinco pedazos de monte que declaran como suyos desde el consentimiento de los concejos afectados y de forma especial el término del lugar despoblado de Vega una vez que se llega a un acuerdo de subscripción de un contrato foral con le concejo de Villalís. El empeño del fiscal, como veremos, por demostrar que el acceso a estas propiedades vino impuesto por el poder jurisdiccional que ostentaba la familia parece confirmarse en la apropiación de estos términos y sus recursos despoblados durante el siglo XVII. En la formalización de los nuevos contratos forales cabe ver intereses mutuos de los concejos y del señor, teniendo en cuenta que estos se formalizan en etapas críticas en las que a la debilidad económica de los concejos se une la imposición señorial a través del control de la justicia ordinaria e incluso de los altos tribunales de apelación. ¿ Porqué aceptaron algunos concejos la firma de estos contratos forales (posteriormente conocidos como fueros malos) que suponían de hecho el reconocimiento de la propiedad o dominio directo del señor y la fijación de unas rentas sobre una parte territorial del término?. Varias pueden ser las explicaciones a partir de considerar la mayor capacidad de oposición de algunas comunidades. En primer lugar hay que hacer constar que para estos pequeños concejos la aceptación de estos nuevos contratos suponía el no tener que pagar los antiguos censos de

\footnotetext{
31 Los señores gallegos intentan territorializar las cargas de origen señorial y hacerlas contractuales a través de obligar a los campesinos a reconocer forales que llevaban implícito el derecho de propiedad. SAAVEDRA,P. "Régimen señorial". Separata de Historia de Galicia. La Voz de Galicia, pág. 531. Este proceso en el que se inserta la problemática estudiada en este trabajo puede verse en VILLARES, R. "Los foros de Galicia. Algunos problemas y comparaciones (Galicia, Portugal y Valencia)”. Leer Historia, 12, 1988.
} 
frutos que eran una fuerte carga, ya que podían suponer el $25 \%$ de la cosecha. Esta situación, que a priori puede parecer perjudicial para el señor, no lo es tanto si tenemos en cuenta que éste logra garantizar una renta fija, a la vez que obtiene un reconocimiento legal a través del contrato foral.

Así pues, este proceso, que parece común a la mayor parte de la nobleza señorial leonesa, aunque con resultados muy desiguales, se va a llevar acabo tanto en el siglo XV, como en los años posteriores al movimiento comunero. Es en estos momentos cuando los señores conocedores de la coyuntura y de sus posibilidades futuras intentan cambiar o modificar las prestaciones de orden señorial o personal y convertirlas en un canon o renta foral fija y en especie que no sólo garantiza perpetuamente la percepción, sino que jurídicamente le acercaba a la propiedad de una tierra que sin la posesión de título alguno de propiedad le era reconocida por un nuevo contrato foral. Con ello, como ya vimos, los señores conseguían trasladar a la tierra existente en cada término o a parte de ella un gravamen que pesaba sobre las personas como vasallos y con ello transformaba definitivamente una relación de derecho público en una relación de derecho privado ${ }^{32}$

\section{Las rentas señoriales: tipología y valoración.}

La propia valoración hecha por la casa señorial sobre las rentas percibidas en los momentos de la abolición del señorío en su confrontación con el estado no sólo es válida para la etapa moderna, dada la estructura, tipología y permanencia del valor de las rentas, sino que nos permite conocer aspectos importantes relacionados con el propio carácter del señorío y con el peso del dominio territorial y solariego, cuestión esta que ha contribuido a establecer por parte de la historiografía ya mencionada diferencias entre el régimen señorial desarrollado en la Castilla interior a partir de un importante dominio y rentas de origen territorial o solariego y aquel que basa su fuerza en las relaciones vasalláticas y en el poder jurisdiccional que permitió incluso el acceso a las rentas enajenadas que suponían el mayor componente de los ingresos señoriales ${ }^{33}$.

\footnotetext{
${ }^{32}$ FLOREZ DE QUIÑONES,V. Notas para el estudio de un foro leonés. Diputación de León,1931,p.36.

${ }^{33}$ A través del seguimiento de la naturaleza de las rentas señoriales se pueden ver importantes diferencias que nos permiten hablar de la existencia de diferentes modelos de señoríos a partir del mayor o menor peso de las rentas agrarias o de las enajenadas a la corona. Así cabe hablar de un modelo asentado en Galicia donde el peso de las rentas agrarias forales suponen el $50 \%$ de unos ingresos, frente a un insignificante peso de las alcabalas. Vid: SAAVEDRA, P. “ Señoríos y comunidades campesinas...”, pág. 439. Un modelo valenciano donde la renta señorial tiene en los censos de frutos o parte de las cosechas su mayor apoyo, en la línea de los censos mencionados en este trabajo(cuartos o quintos) luego transformados en el caso leonés en fueros concejiles,. Vid: MORANT,I. El declive del señorío. Valencia, 1984, pág.80. Un ejemplo castellano similar al caso
} 
Estructura y valor de los ingresos y rentas recibidas por el conde de Miranda en su estado de Palacios e Infantazgo de Valduerna.(1)

\begin{tabular}{|l|c|c|}
\hline Origen de la renta & Valor en reales & $\%$ \\
\hline Arriendos de tierras cobrados en dinero & $\mathbf{2 . 2 6 0}$ & $\mathbf{1 , 8}$ \\
\hline Foros cobrados en dinero & $\mathbf{2 2 2}$ & $\mathbf{0 , 2}$ \\
\hline Rentas de arriendos cobradas en grano & $\mathbf{3 . 1 6 0}$ & $\mathbf{2 , 6}$ \\
\hline $\begin{array}{l}\text { Rentas de foros concejiles cobradas en gra- } \\
\text { no }\end{array}$ & $\mathbf{1 3 . 2 4 0}$ & $\mathbf{1 0 , 8}$ \\
\hline Valor total de las rentas & $\mathbf{1 8 . 8 8 2}$ & $\mathbf{1 5 , 4}$ \\
\hline Derechos de alcabalas. & $\mathbf{8 3 . 8 0 8}$ & $\mathbf{6 8 , 4}$ \\
\hline $\begin{array}{l}\text { Derechos señoriales: pedidos, yantares, ríos } \\
\text { y franquicias. }\end{array}$ & $\mathbf{2 . 3 2 9 , 5}$ & $\mathbf{1 , 9}$ \\
\hline Valor de los diezmos cobrados en dinero & $\mathbf{9 . 0 5 0}$ & $\mathbf{7 , 4}$ \\
\hline Valor de los diezmos cobrados en grano & $\mathbf{8 . 5 1 0}$ & $\mathbf{6 , 9}$ \\
\hline Valor total de diezmos & $\mathbf{1 7 . 5 6 0}$ & $\mathbf{1 4 , 3}$ \\
\hline INGRESOS TOTALES ANUALES & $\mathbf{1 2 2 . 5 7 9}$ & $\mathbf{1 0 0}$ \\
\hline
\end{tabular}

Fuente: Real Carta Ejecutoria. A.M.P. Elaboración propia.

(1) Las cifras hacen referencia a los valores de las rentas en el año 1810, último año de percepción de todas las rentas. En su conjunto se ajustan a la distribución reflejada en los otros estados señoriales leoneses.

En el momento de la abolición del señorío el conde de Miranda, según estimaciones de la propia casa ingresa anualmente rentas por un valor anual equivalente a los $122.579,5$ reales. Una parte de estos ingresos proceden de la valoración hecha sobre los derechos suprimidos sin indemnización dado su carácter eminentemente jurisdiccional (pedidos, yantares, ríos, franquicias o penas de cámara) y sobre aquellos otros que como los diezmos, las tercias y los patronatos han de ser indemnizados por parte del Estado ${ }^{34}$. Ahora bien, los datos de la tabla ponen de manifiesto que el peso de los ingresos anuales de esta nobleza señorial recae

leonés, aunque con matices dado el mayor peso de las rentas agrarias, en el que el valor de las alcabalas superan también el 50\% de los ingresos seguidas de las tercias puede verse en: YUN CASALILLA,B. "Notas sobre el régimen señorial en Valladolid y el Estado señorial de Medina de Rioseco en el siglo XVIII", Investigaciones Históricas, 3,1982, pp.145-176.

34 Aunque en estos momentos del siglo XIX este estado señorial y la casa Bazán está ya integrada en la casa de Alba a través de la casa Miranda y los ingresos de este estado son "de poco peso" con respecto al conjunto anual de los estados de Alba, durante buena parte de la Edad Moderna sirvieron de base al desarrollo de una familia señorial provinciana y de segunda fila que pronto emparentó con otras de ámbito nacional. Dada la estabilidad de las rentas, apoyadas principalmente en las alcabalas encabezadas y en menor medida en las rentas fijas forales, esos ingresos anuales en torno a los cien mil reales colocan a este linaje en la banda media por debajo de otros como la casa de Altamira, Benavente, Luna, etc. 
en aquellas rentas enajenadas o donadas por la corona a favor de ellos en los momentos de formación de los señoríos ${ }^{35}$, por lo que cabe pensar que una vez perdido éste y pese a las promesas de indemnización estos señores se ven obligados a aferrarse a unas rentas agrarias y a un dominio solariego que pese tener un peso y valor muy inferior podía conservar el reconocimiento social de su condición de señores rentistas y contribuir a paliar la "crisis" de sus haciendas. En el caso que nos ocupa, como en la mayor parte de haciendas señoriales leonesas ${ }^{36}$, las alcabalas, pese al sistema de encabezamientos y a la estabilidad de su valor, se convierten en el ingreso más importante y garantizado toda vez que alcanza el $68,4 \%$ del valor total de los ingresos anuales. Si a estas le unimos el porcentaje de las rentas decimales, $14,3 \%$, se puede decir que con el $82,7 \%$ estas rentas o derechos señoriales, factibles ahora de amortización y que tienen sus raíces en los privilegios feudales y en la enajenación de rentas realengas, sostienen básicamente y durante toda la Edad Moderna la economía señorial al ser el pilar fundamental de sus ingresos. Por el contrario, los ingresos y rentas procedentes de la condición vasallática que no habían sido transformados y vinculados al término apenas alcanzan el $2 \%$ de los ingresos. Ante esta situación la única opción que restaba a la casa era la de intentar mantener aquellos ingresos o rentas que suponiendo el $15 \%$ del total estaban totalmente condicionadas y vinculadas al dominio directo de la tierra y a la condición solariega y territorial del señorío. Pese a que, como se ha comprobado y en plena coincidencia con el fiscal del Estado, los señores han impuesto por la vía del poder jurisdiccional y en cierto modo por la imposición coactiva esos contratos forales en los que basan ahora la propiedad, rápidamente se acogen al artículo $5^{\circ}$ del Decreto de 6 de Agosto de 1811 y recurren las sentencias desfavorables en $1^{\mathrm{a}}$ estancia que no reconocen dichos títulos por estar vinculados al jurisdiccional.

\footnotetext{
35 No parece desacertado pensar que buena parte de estas rentas y derechos fiscales le fueron usurpados a la corona en unos momentos de debilidad y de fuerte dependencia de esta nobleza. Con frecuencia el derecho a percibir estas rentas no aparece reflejado en los documentos fundacionales de reyes como Enrique II, mientras que en las posteriores confirmaciones de Juan I, Enrique III, Enrique IV o los RR.CC. ya se hace mención , junto al poder jurisdiccional, a los derechos de percepción de rentas como las alcabalas, diezmos,etc.

${ }_{36}$ En un próximo y amplio estudio sobre los señoríos leoneses veremos la importancia que tuvieron las alcabalas, pese a estar encabezadas, para las haciendas de los señoríos nobiliarios, frente al peso de las rentas agrarias en el caso del señorío eclesiástico. Así, en el Estado de Luna las alcabalas suponen cerca del $50 \%$ de los ingresos en el siglo XVII, mientras que en las jurisdicciones situadas al sur de la provincia dicho porcentaje alcanza al 70\%. En el caso del Marquesado de Astorga las alcabalas, incluidas las de la ciudad, suponen el $78,7 \%$ del valor de todos los ingresos, en la misma línea que la Jurisdicción de Villamañán, perteneciente a la misma casa, en donde las alcabalas de la villa y de los pueblos de la jurisdicción suponen el $87 \%$ del valor de todas las rentas recibidas en 1646.
} 


\section{El conflicto: abolición del jurisdiccional y lucha por el territorial y solariego.}

La abolición del régimen señorial desde la perspectiva legal, jurídica y política cerraba una larga fase de la historia de España que se perpetuó durante siglos teniendo en dicho régimen uno de los principales pilares del Estado Moderno y del sistema capitalista. Sin embargo, dicha abolición si bien potenciaba el poder centralizador del Estado liberal, apartando de el a la nobleza señorial y suprimiendo los estados señoriales, ni mucho menos suponía que esta nobleza quedase relegada, toda vez que era consciente de que, una vez perdida la batalla del jurisdiccional, lo que realmente le interesaba era el solariego o el dominio territorial que había poseído durante siglos ligado al jurisdiccional y en buena medida confundido con él, de la misma forma que parece ocurrirle ahora a los legisladores a la hora de separar la condición jurisdiccional de la territorial. Parece claro que, a diferencia del fiscal bañezano, ni los legisladores, ni las audiencias fueron capaces de dar respuesta a la compleja realidad existente en unos señoríos en los que los señores, partiendo del poder jurisdiccional e interpretando de una forma muy peculiar los títulos $\mathrm{y}$ mercedes a su favor, aseguran en mayor o menor medida un dominio solariego y territorial. Según M.Artola la causa de esta situación está en que aquellos legisladores y jueces carecían de una formulación teórica correcta en relación a las instituciones sobre las que legislaban o juzga$\mathrm{ban}^{37}$

E1 2 de Diciembre de 1837 el juez de primera instancia de La Bañeza dictaba sentencia sobre la supresión de todos los derechos hasta esos momentos percibidos por la Condesa de Miranda, esposa del Duque de Liria y Alba, al amparo de la nueva legislación por la que se suprimía el régimen señorial. A través del administrador general y apoderado de la señora en La Bañeza la condesa interpone recurso a fin de que independientemente del abolido jurisdiccional se le reconozca el señorío territorial y solariego de Palacios e Infantazgo de Valduerna al amparo del Decreto de 6 de Agosto de $1811^{38}$. Se trataba, pues, de restablecer por la vía

\footnotetext{
37 ARTOLA, M. Antiguo Régimen..., p. 171.

${ }^{38}$ En dicho decreto se diferencian las prestaciones así realengas como personales que deban su origen al título jurisdiccional de aquellas otras que procedan de contrato libre en uso del signado derecho de propiedad... En el artículo $5^{\circ}$, a su vez, se dice que los señoríos territoriales y solariegos quedan en esa clase de los demás derechos de propiedad particular, a lo que se añade que los contratos, pactos o convenios que se hayan hecho en razón de aprovechamientos, arriendos a terceros, censos u otros de esta especie, celebrados entre los señores y vasallos, se deben considerar desde ahora como contratos de particular a particular... El caso que nos ocupa, como se verá, se va a fundamentar en esta legislación.
} 
judicial de apelación y aprovechando las nuevas circunstancias políticas y sociales el señorío territorial y solariego, así como las correspondientes rentas y derechos emanados de él. Después de un largo pleito la causa se cierra en 1848 con una sentencia favorable a la casa Miranda que es recogida en la Real Carta Ejecutoria que nos ha servido para conocer importantes aspectos de esta lucha de la nobleza por perpetuar su poder sobre la sociedad campesina.

Una vez que el Estado a través del fiscal y de la Audiencia bañezana notifica a los vasallos y lugares pertenecientes al antiguo señorío las intenciones de los señores, son los concejos más afectados por las nuevas pretensiones señoriales ( Villalís, Palacios ) los que se oponen y no reconocen la demanda de la casa al no presentar ésta los correspondientes títulos y derechos en el plazo y término marcado por la nueva ley de 26 de Agosto de 1837. Por tanto, no considera como propiedad particular del conde el señorío, rentas y demás derechos ya que no cabe declarar como propiedad particular los emolumentos, rentas y derechos que el conde había percibido porque todos tenían un origen feudal y esos privilegios habian quedado abolidos.

Si en un principio parece detectarse una cierta disposición de los concejos a posicionarse frente a las pretensiones de los señores, especialmente a la hora de no reconocer determinadas rentas forales que disfrazadas de martiniegas habían conseguido, como vimos, imponer sobre los términos o sobre determinados espacios comunales, su posición va a cambiar muy pronto motivada por dos nuevas situaciones: la renuncia de los señores a determinados derechos forales ( martiniegas o fueros malos), situados de forma abstracta sobre el término y sin vinculación directa a una tierra determinada, y las pretensiones oficiales de que esos bienes raíces de difícil justificación en cuanto al origen de su propiedad pasasen al patrimonio del estado. La consideración del fiscal y de la audiencia de que los derechos reclamados por los señores son disputables únicamente cuando se trate de entablar demanda de reversión a la Coro$n a$, negando así cualquier posibilidad de recuperar el dominio concejil provoca la puntual respuesta de aquellos concejos que en un principio estaban dispuestos a plantar cara a los señores en sus pretensiones de reconocimiento del territorial y solariego. ¿Porqué iban ellos a pleitear por unos bienes y derechos que, a la postre, iban a pasar a la titularidad del Estado?.¿ Acaso el cambio de titularidad les iba a beneficiar a la hora de usufructuar unos bienes comunales que habían controlado y repartido durante siglos a cambio de unas rentas forales cuyo valor apenas se había 
modificado?. ¿Qué iba a pasar con esa tierra y con esos recursos o infraestructuras hídricas como la zaya o rauda de la que se habían beneficiado durante siglos mediante el entendimiento mutuo con el señor?. Detrás de la respuesta a estos interrogantes parece ocultarse la justificación de varios concejos, como el de Villalís, enfrentados judicialmente con los señores por la titularidad y aprovechamiento de la dehesa titulada del conde $^{39}$. Logrado el acuerdo con el concejo de Villalís la estrategia del conde y de sus administradores parece dirigirse ahora a ganar la confianza de los concejos y hacer que estos no sólo se aparten de cualquier demanda judicial o pretensión territorial, sino que declaren a su favor a la hora de reconocer viejas y seculares prestaciones y dependencias vinculadas de alguna forma al dominio solariego y territorial ahora reclamado. Con el apartamiento de los concejos no sólo quedaba sólo el fiscal, sino que el conde había logrado ganar una primera batalla a cambio de "comprar" a los vasallos y concejos bajo la promesa de mantener y no modificar las antiguas relaciones de producción .

En este contexto, a finales de 1837 la casa de Alba no sólo se enfrenta claramente al Estado, sino que basa todas sus pretensiones, de acuerdo a la nueva ley, en las escrituras notariales y reconocimientos forales hechos con los vasallos y concejos durante la Edad Moderna y fundamentalmente aquellos firmados, supuestamente por vez primera, en la década de los años treinta del siglo XVI. Esta década no es casual, sino que, como se verá, en ella coinciden una serie de factores claves para el futuro de estas tierras, tales como el fuerte desarrollo demográfico, económico y roturador y la propia posición social y jurisdiccional de los Bazán, toda vez que salieron triunfantes en el movimiento comunero mediante el apoyo ofrecido al rey en Villalar. Es posible que el ejemplo que mejor ilustre esta situación sea el ofrecido por Miñambres y Santa María de la Isla, dos de los concejos que supuestamente manifestaron su apoyo a la Junta comunera en 1521. El concejo de Santa María de la Isla se ve obligado ya en 1523 a plantear pleito judicial a los señores ante las pretensiones de estos de hacerle pagar un censo de frutos o renta por los terrenos comunales que usufructúa y necesita roturar ante el crecimiento del vecindario. La sentencia definitiva de la Chancillería de Valladolid en 1532 a favor de los señores de Bazán obliga al concejo y vecinos a reco-

\footnotetext{
${ }^{39}$ El concejo de Villalís no sólo cuestiona la titularidad de la mencionada dehesa, sino que se opone a pagar derecho alguno por sus aprovechamientos, pese a que habían sido pagados durante siglos por sus antepasados sin plantearse la justificación de la titularidad. El conflicto judicial parece llegar a su fin en 1837 cuando el administrador del conde llega a un acuerdo con el concejo a cambio de que se retracte de la demanda. A cambio de no cuestionar la titularidad le ofrece la gratuidad de los aprovechamientos.
} 
nocer un fuero o foro perpetuo por razón de casas y heredades e por razón de arrotos que poseen... y en concepto de pan de fuero e censo ${ }^{40}$. Esta nueva situación que parece afectar a una parte de los concejos, especialmente a aquellos que fueron rebeldes en la causa comunera, se plasma definitivamente a lo largo de esa década con los consiguientes reconocimientos forales por parte de los concejos a favor del señor. Estos nuevos fueros enfitéuticos suscritos bajo las circunstancias apuntadas no sólo van a marcar un antes y un después en las relaciones vasalláticas, sino que, como veremos, van a servir de base jurídica legal para fundamentar las sucesivas apelaciones y las pretensiones de la casa de que se le reconozca el dominio sobre unos bienes que ahora ha logrado situar y fijar dentro de cada término. La clave ahora va a estar en la interpretación de la nueva ley y en demostrar la validez de los títulos de propiedad aportados por la casa y de los testimonios presentados que reflejan una nueva posición de los concejos.

\subsection{El proceso en primera instancia y los títulos aportados.}

El 22 de Abril de 1840 el juez de primera instancia de La Bañeza y su Partido en vista de los autos y pruebas aportadas por la casa declaraba no ser de propiedad particular de la Excma Sra. Condesa del Montijo y Miranda el señorio de Palacios de la Valduerna y su Infantazgo, reservando como reserva a las partes las acciones que les competan para que las deduzcan en el juicio correspondiente con arreglo a las Leyes de Señoríos. El problema, como ya apuntamos, se había planteado a raíz del Decreto de Cortes de 23 de Agosto de $1811^{41}$, artículo que había dado pié a los señores para intentar presentar títulos que justificasen el origen de las rentas percibidas. La sentencia anterior estaba motivada por la incapacidad de aquellos de presentar documentos que demuestren la forma de adquisición de los bienes raíces sobre los que ha de basarse el reconocimiento pretendido de solariego y territorial. Esta misma causa parece

\footnotetext{
40 En la sentencia definitiva y en la posterior escritura de fuero o censo de frutos suscrita por el concejo y vecinos de Santa María de la Isla se condena y obliga a pagar a éstos veinticinco cargas de pan terciado por los aprovechamientos que hacen de sus casas, tierras comunales (heredades) y por los arrotos (nuevas roturaciones) una carga y media de pan mediado. Además de esto se obliga al concejo a reconocer otras cargas y prestaciones comprendidas en un yantar de 74 reales por S. Martín, valor de dos vacas, tres terneros y dieciséis cántaras de vino. A su vez, cada vecino pegujero (pechero) ha de pagar también por S. Martín el valor de una gallina y las viudas media, de la misma forma que cada vecino que ponga era y coja leña ha de pagar el valor de un carro de paja y otro de leña. Junto a estas cargas justificadas en especie pero percibidas en dinero el citado concejo se obliga a pagar la parte que le corresponde del pedido pagado desde inmemorial tiempo por todos los concejos de la Valduerna y repartido por los Jurados de la Tierra.

41 Dicho artículo, sancionado por el rey expone que si los señores territoriales presentaban los títulos de adquisición dentro del término señalado se les continuasen pagando las prestaciones, rentas y pensiones hasta que recaiga sentencia que cause ejecutoria.
} 
estar detrás del Real Auto que en grado de vista dictó la sala primera de la Audiencia Territorial de Valladolid en 1841 al negar a los señores el carácter territorial y solariego de su señorío ${ }^{42}$. Nuevamente será en 1844 cuando la sala segunda de la citada Audiencia confirme el Real Auto de vista dado por los jueces de la sala primera. Posteriormente se remite dicho acuerdo con el pleito original al juez de primera instancia ante quien la condesa presenta nuevamente la demanda en 1846, pero ahora centrada en un nuevo planteamiento una vez ganada la voluntad de los concejos más díscolos. En efecto, se trata de una nueva estrategia tendente a demostrar que el territorial y solariego poseído y las correspondientes rentas recibidas tenía su origen en los correspondientes contratos forales suscritos antiguamente con concejos y vasallos dentro del marco establecido por el derecho común ${ }^{43}$. Así pues, amparándose en el artículo sexto del Decreto mencionado, la condesa sostiene que todos los contratos, pactos o convenios hechos entre los antes llamados señores y vasallos, debian considerarse como contratos de particular a particular... máxime cuando se acepta que dichos contratos habian sido libres y espontáneos por ambas partes, toda vez que no se prueba violencia o coacción y eran válidos y como tal debían respetarse en uso del sagrado derecho de propiedad. Este derecho, recogido por el artículo cuarto del Decreto de 1811 , va a servir de base a una nueva argumentación tendente a demostrar el carácter particular y mercantil de los títulos que apoyan su dominio solariego, pese a que la legislación reformista posterior introduzca nuevos matices, a raíz de los problemas surgidos en torno a los señoríos valencianos y andaluces ${ }^{44}$. Pero, mientras que la nueva legislación de

\footnotetext{
42 Esta sala declara que los títulos presentados a nombre de la Excma. Sra. Condesa no son suficientes para considerar territorial y solariego el señorio de Palacios de Valduerrna y su Infantazgo, ni por consiguiente haber lugar a mantenerla en la posesión de percibir las prestaciones rentas u emolumentos procedentes del propio señorío procediéndose en su virtud al secuestro de las mismas...

${ }^{43} \mathrm{La}$ argumentación de la parte demandante afirma que es cierto que el referido decreto de Cortes de mil ochocientos once abolió para siempre todos los señorios jurisdiccionales y cuantas prestaciones, así reales, como personales, tuvieran aquel origen, pero exceptuó, como no podía ser menos, las que procediesen de contrato libre entre partes en uso del sagrado derecho de la propiedad... declaró también que los señores territoriales y solariegos quedaban en la clase de los demás derechos de propiedad particular, a no ser de los que por su naturaleza deban incorporarse a la nación o de los en que no se hayan cumplido las condiciones con que se concedieron; y como esta circunstancia no podía averiguarse al no tener a la vista los títulos de adquisición fue muy consiguiente que el artículo nono ordenase la presentación de aquellos en las chancillerías y audiencias, según la organización judicial de la época, y esa presentación se ordenaba, no para todos los casos, sino tan solamente para el previsto en el artículo octavo, a saber: cuando los señores perdiendo las prerrogativas de que trataba el séptimo y habiéndolas obtenido por títulos onerosos creyesen deber reclamar su reintegro e indemnización, ora por haber pagado un capital, ora por recompensa de grandes servicios reconocidos.

44 En la misma argumentación del representante de la condesa se hace referencia a la petición hecha por la Audiencia de Valencia a las Cortes en relación al artículo quinto y a la necesidad de que los señores presenten los correspondientes títulos, petición que generó una larga discusión hasta la promulgación en 1823 de una nueva ley que a juicio de la parte demandante en nada variaba la consideración de los señoríos solariegos y
} 
1823 y de 1837 trataba de aclarar las cuestiones planteadas por los tribunales en relación al jurisdiccional y al solariego, la confusión parece mantenerse toda vez que la nobleza, amparándose en el sagrado derecho a la propiedad particular en modo alguno cuestionado por las respectivas leyes, se acoge ahora al derecho común y a los contratos y títulos que pese a tener un origen jurisdiccional fueron transformándose por vía impositiva en contratos mercantiles. Nuevamente, pese a la posición de la ley de 1823 , los señores se acogen al artículo $5^{\circ}$ del Decreto de 1811 por el que los contratos establecidos y firmados por señores y vasallos se han de considerar fuera de cualquier condición jurisdiccional. A la luz de la nueva ley de 1837 y de la plena validez del citado decreto tan sólo le faltaba a la casa presentar esos contratos y ganar para su causa a vasallos y a los concejos afectados.

Así pues, explicados los pormenores de las leyes y desde la afirmación de que nada hay, pues, establecido de particular para los señoríos de esta clase, están colocados por el silencio de las leyes dentro del derecho común, el siguiente paso es intentar demostrar que en los diferentes títulos que posee la casa otorgados por los reyes de Castilla durante la Baja Edad Media se les reconoce, aparte del jurisdiccional, el territorial y el solariego ${ }^{45}$. Es, pues, a partir de la Real Carta de 1439 cuando por vez primera aparecen reflejados derechos señoriales sobre términos y sobre una tierra que, como ya apuntamos, estaba en su mayor parte privatizada y controlada por las comunidades concejiles. En torno a esta Real Carta va a girar la argumentación de la casa en el nuevo pleito al considerar que no cabe incorporación ni reversión a la Corona de un dominio o señorío territorial cedido por el rey y que va más allá del mero jurisdiccional al referirse a la propia tierra. Las confirmaciones recogidas posteriormente y despachadas por los Reyes Católicos en 1477 y 1486 vuelven

\footnotetext{
territoriales como de propiedad particular. Posteriormente tampoco la ley de Agosto de 1837 modificaba nada respecto a los juicios de propiedad que supuestamente habían de desarrollarse de acuerdo al derecho común.

45 Incluso se recurre a recoger la Real Cédula de Felipe V de 1709 y otra de 1752 en la que se ratifica al Conde de Miranda el derecho a seguir percibiendo las rentas y derechos otorgados por los mencionados títulos. En primer lugar se recoge el título por el que Enrique II crea el señorío en la figura de Juan González Bazán en 1366 y las sucesivas confirmaciones de los reyes, aunque en ellas apenas se especifica sobre el contenido de la donación más allá del poder jurisdiccional. La propia donación considerada como una merced enriqueña sujeta a restitución según el propio testamento del monarca es cuestionada en los primeros años del reinado de Juan II toda vez que el propio fiscal del estado demanda a Pedro de Bazán y solicita la incorporación del señorío a la corona. Pero, los acontecimientos políticos y los buenos y leales servicios que Pedro de Bazán había hecho al rey en las guerras de Aragón y de Navarra hicieron que el propio rey Juan II no sólo renunciase al pleito de incorporación, sino que a través de una Real Carta reconoció en 1439 que el mencionado señorío comprendía las aldeas, tierras, jurisdicciones términos, distritos, derechos, alcabalas y tercias... prohibiendo e inhibiendo perpetuamente a todos los fiscales y jueces, renunciando cualquier derecho que a favor de la corona o del fisco pudiera alegarse.
} 
a hacer referencia a los buenos e leales servicios y a la cesión de todo sus términos y territorios, además del jurisdiccional, lo que le sirve para justificar el denominado señorío territorial ${ }^{46}$.

En efecto, la clave del futuro éxito parece estar en demostrar que tanto las rentas particulares(solariegas), como los foros enfitéuticos concejiles (territorial), a diferencia de otras como las alcabalas o yantares, tienen su origen en una cesión territorial por parte de los reyes y en los sucesivos contratos suscritos y reconocidos por concejos y vasallos. Pero, pese a la persistencia por parte de los señores de vincular el dominio territorial a la mera propiedad particular, éstos siguen sin aportar títulos de propiedad más allá de aquellos vinculados al jurisdiccional.

\subsection{El cuestionamiento de los títulos y las reflexiones del fiscal.}

El 6 de Febrero de 1847 el fiscal del juzgado de primera instancia de La Bañeza D. Anselmo García Serantes no sólo demuestra un alto nivel de formación y conocimientos de las leyes, sino que solicita del juez que se sirva absolver al Estado de la demanda interpuesta por la condesa y le imponga a ésta silencio y costas. A su vez solicita la incorporación a la nación del territorio de Palacios de Valduerna con sus agregados. Pero, pese a su formación y conocimientos, dicho fiscal no se daba cuenta de que al solicitar la enajenación de estos denominados territorios estaba reconociendo el dominio territorial poseído por la condesa. Tan sólo restaba que la propia señora, reconocido y situado el dominio, demostrase su propiedad con la propia ayuda de los concejos y vasallos. Otra cosa muy distinta hubiera sido si en dicho pleito el fiscal no hubiese pretendido que los expresados bienes y territorios comunales asentados en cada término no revirtieran a la corona, sino a los propios concejos a quienes se le habían usurpado. No cabe duda de que la posición de estos concejos y de los vasallos hubiera sido totalmente distinta. Una vez que los pueblos se habían apartado del pleito el fiscal centra toda su estrategia en demostrar que todos los títulos, rentas y derechos recibidos, incluidos los forales, tenían su origen en el jurisdiccional. Pero, el pleito había tomado ya un nuevo giro que a la postre iba a cambiar el resultado final. Este giro se lo va a proporcionar la parte demandante una vez que gana

\footnotetext{
${ }^{46}$ Para demostrar este dominio territorial se hace referencia al pleito perdido por el concejo de la Isla en 1532 y el posterior reconocimiento de Carlos I al que habían servido fielmente los Bazán en las Comunidades. En aquel pleito, en el que el concejo se negaba a pagar veinticinco cargas de pan en concepto de foro, se dilucidaba el dominio que los señores pretendían tener sobre el término y las heredades comunales roturadas, lo que ha de relacionarse con la mayor capacidad de imposición por parte de los señores y la posición de debilidad de aquellos concejos que de alguna forma apoyaron la causa comunera.
} 
para su causa a los concejos y vasallos quienes reconocen a través de los contratos suscritos por sus antepasados el dominio territorial de los señores y la propiedad no ya del término y de otros recursos comunales, sino de aquellas heredades comunales repartidas entre los vecinos que pretendían seguir usufructuando en las mismas condiciones anteriores. Caso de ganar el fiscal y una vez que éstas hubieran pasado a la Corona esas posibilidades iban a desaparecer.

Pese a ello, la estrategia del fiscal va a girar en torno a la cuestionada validez mercantil de los títulos aportados por la condesa, títulos que no sólo vincula totalmente al jurisdiccional, sino que llega a cuestionar en su validez dado que fueron otorgados por Enrique II en 1366 cuando aún no era rey de Castilla ${ }^{47}$. De la misma forma se afirma que los posteriores títulos y conformaciones de los reyes de Castilla no son testimonios de escribanos públicos, sino de los propios administradores de la casa Miranda, lo que le invalida como prueba... . Pero, incluso el fiscal va más allá y apoyado en el libro X de la Novísima Recopilación afirma que el Estado pudo legalmente incorporar a la Corona este señorío $^{48}$, máxime cuando se ha demostrado ahora que los títulos no son originales y cuando la propia Novísima reconoce que el propio rey Enrique II el generoso puso en su testamento remedio a sus prodigalidades, hijas de la situación en la que se colocó con respecto a sus parciales en la sangrienta guerra civil que sostuvo con su hermano. El interrogante que se plantea el propio fiscal es significativo y refleja una fuerte convic-

\footnotetext{
47 Se ve en la fecha de la merced del Rey D. Enrique II, de donde trae causa de poseer este estado la casa de Bazán, transcrita en el privilegio de confirmación del rey D. Juan I una muy notable equivocación que bastaría al reputar dudoso de aquel documento y consiste en que se supone que el referido rey $D$. Enrique segundo hizo esta merced en Calahorra a veinte y dos de marzo de la era de mil cuatrocientos cuatro... que corresponde al año de Nuestro Señor Jesucristo de mil trescientos sesenta y seis... y sin embargo el citado D. Enrique no pudo titularse rey ni lo fue de derecho hasta el catorce de Marzo de mil trescientos sesenta y nueve, en cuyo día falleció su hermano en los campos de Montiel. Y si por ventura se quisiera decir que ya en aquella época en vida del rey D. Pedro era monarca reconocido por algunos pueblos y cortes extranjeras que le ayudaron a sostener las guerras nos hallaremos con que el contexto de la escritura se ha de entender que D. Pedro era ya muerto y no obstante no deja de causar extrañeza que después de haberse afianzado en el trono D. Enrique no hubiera ratificado esta merced y que hubiese habido necesidad de esperar a confirmarla el Rey D. Juan I, su sucesor, en los primeros meses de su reinado. Todo esto indica que tal merced, hija de la privanza y el favoritismo, fue como muchas otras debida a un albalá tal vez firmado en blanco, como de este modo de haberse desprendido en lo antiguo los monarcas, terminantemente lo dicen las leyes del título V, libro tercero de la Novísima Recopilación, que declaran nulas tales donaciones... Real Carta Ejecutoria, pp. 149-150.

${ }^{48} Y$ en verdad que no son los documentos de esta clase los que leyes desean para que pueda juzgarse de propiedad particular un territorio en el que ha ejercido jurisdicción un señor que lo fue de vasallos. Todos estos documentos están respirando feudo, todos están demostrando que su adquisición en la casa de Bazán proviene de una merced real que ha caducado y cuyo territorio, habiendo salido de la corona, hace muchas generaciones que debió haber revertido a ella o al estado, si los encargados de ejecutar las leyes de ese derecho común que se invoca para pretender encerrar las recientes de señoríos, no hubiesen tenido tanta indebida tolerancia. Real Carta Ejecutoria, pp.150-151.
} 
ción liberal: ¿ Qué diremos en vista de esto ahora que la legislación vigente deja sin efecto las mercedes y donaciones reales de esta clase? ${ }^{49}$. Solamente, pues, puede demostrar la parte litigante su posesión mediante la aportación de documentos que hayan sido adquiridos por los medios legales que autoriza el derecho común(compra-ventas), es decir adquisiciones de contrato libre e independiente de las mercedes reales.... Ante esto, ante las pruebas aportadas y después de ver con anterioridad la propia distribución de las rentas generadas y la tipología del dominio territorial no cabe duda de que la propiedad territorial y solariega demandada por la condesa en modo alguno se obtuvo mediante contratos libres, sino a partir del poder jurisdiccional y de la mayor o menor capacidad que tuvieron los Bazán para imponerse a los concejos. Pero, algo parece escapársele al fiscal cuando insta a la condesa a que no use argumentos cauciosos apoyados en títulos insuficientes, y solicita la incorporación a la Corona de los bienes demandados cuyo origen sitúa en la donación foral hecha por los reyes a sus vasallos, especialmente de tierras comunales, posteriormente vinculadas por los señores a través del feudo ${ }^{50}$. Es posible que no calculase en su justa medida el valor de los contratos forales finalmente aportados junto a los testimonios de los propios vasallos y concejos.

\subsection{La estrategia final: nuevos documentos y la interesada adhesión de vasallos y concejos.}

En Febrero de 1847 el promotor fiscal, después de demostrar un buen dominio de la legislación antigua y nueva, concluye su exposición solicitando silencio y pago de las costas para la condesa de Miranda , así como la incorporación del territorio señorial a la Nación. Sin embargo, algo había cambiado respecto a la primera fase del proceso, comenzando por la propia actitud y disponibilidad de los concejos afectados y por la sospechosa retirada de aquellos que en los primeros años habían entrado en pleitos con la casa cuestionando lo mismo que el propio fiscal. ¿ Porqué cambiaron los concejos de actitud y porqué no comparecen a la llamada y a los autos del fiscal?. La respuesta a este interrogante solamente puede hallarse, como ya apuntamos, si valoramos la situación que podía

\footnotetext{
$49 \mathrm{Al}$ respecto y siguiendo su argumentación afirma el fiscal que todas las leyes promulgadas sobre señorios desde mil ochocientos once no tienen otro efecto que dejar sin efecto las leyes antiguas y modernas que autorizaban las donaciones, mercedes y confirmaciones, concedidas por los monarcas de lugares y territorios que se desmembraron de la integridad de la nación en beneficio de señores y particulares... Idem, pág.154. ${ }_{50}$... puesto que esos terrenos que a sus antiguos vasallos dio a foro ( el rey) eran correspondientes al territorio donado por los reyes y esos montes y demás predios que disfrutó en ambos dominios carecen de título que manifieste su origen diferente del feudo... Idem, pág. 155.
} 
generar dicha demanda caso de prosperar y pasar esos bienes, hasta ahora usufructuados por los concejos, a manos de la Nación. Aquí está, sin duda, la clave de la nueva estrategia señorial y de la actitud de los afectados que conduce al final al triunfo de los demandantes.

En esta nueva línea de actuación se trataba de recuperar, conforme al decreto de 1811, todas las escrituras y contratos forales de obligación que desde el siglo XVI y hasta el siglo XIX habían firmado los campesinos y concejos con los señores, así como las rentas generadas por estos, especialmente los realizados en el ya referido año de 1533 después del triunfo realista sobre los comuneros y el más que cierto sometimiento de los concejos, algunos de ellos rebeldes, por parte del triunfante Pedro de Bazán. A su vez, una vez ganada la confianza de los pueblos y concejos, se trataba de buscar la directa declaración de testigos, especialmente en el reconocimiento de rentas forales pagadas por los concejos, en principio sobre espacios no delimitados e incluidos bajo la fórmula de término y posteriormente sobre una parte de aquel roturado y administrado bajo el dominio concejil. En este contexto las pretensiones territoriales sobre el término despoblado de Vega, una vez que la casa había vendido a principios del siglo XVIII a los Castañón de La Bañeza el otro despoblado de Hinojo, parecen tener éxito ya que en 1670 el concejo de Villalís suscribe con los marqueses una escritura de foro por la que se le cede el aprovechamiento y usufructo de todos los recursos del término, hasta que hipotéticamente vuelva a poblarse, a cambio de una renta anual de cinco cargas de grano ${ }^{51}$. Pero, la importancia de esta escritura o reconocimiento foral no está tanto en la renta percibida cuanto en que a partir de ella los señores adquirían por vez primera un título de propiedad, sin que nadie, ni el estado, ni los vasallos reclamasen el domi-

\footnotetext{
${ }^{51}$ A.H.P.L. Caj.7344. Año 1704 “... el lugar de Villalís ha muchos años que ha gozado del rozo, pasto, aguas, y aramios del despoblado de Vega por escritura de foro que habían otorgado a favor de la casa de su Excelencia(1670) y por razón de ello pagaban cinco cargas y una fanega de pan mediado en cada año... y por parte de Gaspar Martínez, vecino de Posada y Torre se pretendió tomar a foro dicho despoblado y ofreció seis cargas y media de pan mediado y veinte reales por las alcabalas... y habiendo llegado esto a noticia de los vecinos y concejo de Villalís se acudió a su Excelencia para que por el tanto que otra persona diese fuese preferido dicho concejo y vecinos en tomar dicho foro y su Excelencia lo tuvo por bien... y se le aforó el término común de pastos, abrevaderos,prados, aguas,rozo, aramios que le pertenecen para que el concejo y vecinos de dicho lugar de Villalís se puedan aprovechar y usen según y en la forma que los vecinos que fueron de dicho término y lugar despoblado lo hicieron y con los lugares de Posada y la Torre, Valle,Fresno,Castrotierra, Robledino y Robledo... . Es condición que si en algún tiempo se volviese a poblar dicho término y lugar de Vega ha de ser visto cesar este foro y no pueda tener fuerza ni efecto esta escritura y se ha de transferir en su Excelencia el útil de dicho término y todo el derecho que a él le pertenece para que lo pueda dar a los vecinos que fueren de dicho lugar de Vega a foro.... Es condición que el concejo de Villalís tenga la obligación de hacer cada tres años apeo y amojonamiento de las arcas y mojones de dicho términо..".
} 
nio. Cuando esto ocurre, caso del concejo de Villalís, tanto el favor de los tribunales hacia los señores y la capacidad coactiva de estos, como los altos costes de los pleitos, se nos presentan como los factores responsables de que los señores no tuvieran problema alguno a la hora de culminar el proceso de apropiación de los términos despoblados y asentar así las bases de su pretendido dominio territorial.

A su vez, el hecho de que muchas de las nuevas escrituras presentadas ahora por la condesa, con fecha posterior al decreto de abolición de los señoríos e incluso en los inicios del pleito, viene a demostrar el acuerdo previo existente entre los representantes de la casa señorial y los campesinos foreros o arrendatarios ante la petición del fiscal de que dichos bienes pasen a la nación. Pero, donde mejor se aprecian las contradicciones de la casa Miranda, al pretender el reconocimiento de su dominio territorial sobre todo el Infantazgo de Valduerna, es en la documentación presentada referente a los fueros concejiles y en la aportación de los testimonios de unos testigos comprados que, lejos de demostrar el origen de la propiedad a través de un simple contrato mercantil, lo que demuestran es que detrás del uso y aprovechamiento inmemorial está el poder jurisdiccional y la condición señorial ahora abolida. En efecto, el interrogatorio en cuestión se va a centrar en la demostración, siempre desde el reconocimiento del usufructo inmemorial por parte de los testigos, que tanto los cauces de agua, acequia denominada como Rauda, como otros recursos no privativos existentes en el denominado término del señorío habían estado bajo la propiedad de la casa, lo que justifica que todos los molinos levantados en dicha acequia por los vasallos, previa autorización del señor, pasen a ser foreros de él $1^{52}$. A partir de la titu-

\footnotetext{
${ }^{52}$ El interrogatorio en cuestión al que se somete a los testigos consta de seis preguntas: en la primera se interroga sobre si es cierto que el cauce titulado de la Rauda que se toma del río Duerna en el término de Destriana y desagua en Palacios, con cuyas aguas se fertilizan los pueblos y términos de Robledo, Robledino, Palacios y otros pueblos fue hecho y construido a expensas de los referidos Condes de Miranda como dueños territoriales de todo el Infantazgo.; si es cierto que los expresados señores hicieron donación graciosa a los expresados pueblos del disfrute del propio cauce de la Rauda...; si es cierto que el orden de aprovechamiento del agua se ha guardado siempre... siendo indispensable para que los terrenos regables produzcan abundantes frutos en términos de que sin el expresado riego serian áridos y de poca producción cuando hoy son de los más fértiles y sustanciosos; si es cierto de que si cualquier vecino de la Valduerna quisiese construir un molino sobre la expresada Rauda ha pedido y tiene que pedir licencia a su Excelencia como señor territorial de la misma y de su exclusiva propiedad aforando el sitio que ocupa aquel artefacto; si es cierto que en la propia forma cualquier vecino de Palacios que pretenda levantar casa ya sea al pie de la muralla de aquel pueblo, ya fijando sobre la misma ha solicitado igualmente el foro del término, como lo han hecho hasta ahora todos sus confirmantes...; si es cierto que por razón de la propiedad territorial que a la casa corresponde en el estado e Infantazgo de Palacios y Valduerna percibe en los respectivos pueblos las pensiones forales y demás rentas a dinero y en grano que constan en las certificaciones...; si es cierto que las fincas y heredades que traen en foros los concejos y particulares las tiene su Excelencia como propiedad particular y
} 
laridad de la construcción de esta conducción de agua, ratificada por los propios testigos y por los usufructuarios, la condesa pretende justificar un dominio solariego en clara correspondencia con el territorial reclamado desde la consideración de señora del término de cada concejo. A ello $\mathrm{y}$ al resultado final parecen ayudarle las declaraciones de los testigos que ratifican las afirmaciones del interrogatorio, pero que a juicio del fiscal nada aportan en cuanto a los documentos de propiedad, sino simplemente de uso ${ }^{53}$. En efecto, la clave está en que pese a las declaraciones de los testigos en modo alguno quedaba demostrado el origen y la procedencia libre a través de contratos de compra o adquisición, pues una cosa era la realidad contractual manifestada y aceptada por concejos y vasallos afectados y otra la titularidad o dominio territorial sobre cada uno de los términos administrados por cada comunidad o concejo ${ }^{54}$. La referencia al término, pues, no valía mientras no se fijara territorialmente las posesiones ya que la mayor parte de este era privativo de los vasallos. Por otra parte, la fijación del dominio por parte de la casa a partir de heredades forales, pese al reconocimiento de los encausados, tampoco valía en tanto en cuanto sólo se demostraba el uso, pero nunca la plena propiedad mediante un título que no fuera el abolido jurisdiccional.

Así las cosas, en Enero de 1848 el juez de primera instancia de La Bañeza dicta sentencia a favor de la Condesa de Miranda. La correspondiente apelación por parte del fiscal no prosperó y el 23 de Agosto de ese mismo año era la sala primera y posteriormente la segunda de la Audien-

\footnotetext{
como tal se ha reputado siempre: una heredad de tierras...(sigue la relación de las heredades). Real Carta Ejecutoria, pp.401-408.

${ }_{53}$ Rufino Gimeno, vecino de la villa de Palacios dijo ser cierto el contenido de la posición a que contesta por ser un hecho público en toda la Valduerna.. y que las aguas que salen del cauce titulado de la Rauda son las que fertilizan los campos de los términos y pueblos de Robledo, Robledino, Fresno, Villalís, Castrotierra, parte de Miñambres y Palacios... y ha oído a muchos ancianos que entre el señor de Destriana y el conde de Miranda hubo cierto convenio para la permisión de abrir dicho cauce permutando un terreno por otro, habiendo oído que el conde dio al señor de Destriana un pedazo de monte en término de dicho pueblo en cambio del que le tomó para el cauce... y los molinos que se hallan construidos en dicha Rauda pagan una pensión foral en cada año... Después de contestar afirmativamente al resto de preguntas el testigo dijo en relación a la $6^{\mathrm{a}}$ que es cierto que por razón de la propiedad territorial que corresponde a la casa de su Excelencia.... percibe en los respectivos pueblos las pensiones forales y demás rentas a dinero y en granos que constan en la certificación que se le acaba de manifestar y leer, procediendo todas ellas de los terrenos que han dado a foro los poseedores de este señorío, tanto a los concejos como a los vecinos particulares... Real Carta Ejecutoria, pp.410-423.

${ }^{54}$ Las conclusiones del fiscal en la pág. 21 de dicha Ejecutoria reflejan realmente la realidad: según el contexto de los documentos presentados Juan G. Bazán y sus sucesores habian adquirido la jurisdicción en el infantazgo con la adicción muy común en tales ocasiones de que la obtenía con todas las rentas, pechos e derechos haciendo indicaciones a términos y territorios, pero sin expresión particular de cuales podian ser estos o que prestaciones pudieran representarlos y que por lo mismo era muy cierto que los derechos del Estado y de los pueblos se hallaban en toda su integridad por no representarse en los títulos traidos al proceso una prueba clara y terminante del señorio territorial...
} 
cia Territorial de Valladolid quien en Diciembre dicta sentencia definitiva reconociendo los Estados de Palacios y Valduerna de propiedad particular procedente del señorio territorial y solariego, independiente del abolido jurisdiccional que conjuntamente ejercieron en ellos los causantes de dicha señora. A petición de parte se expide la correspondiente Real Carta Ejecutoria por la que definitivamente se le reconoce el dominio directo o propiedad de aquellos espacios que consiguieron delimitar en los diferentes términos de los lugares bajo su jurisdicción. Eran, pues, los ganadores, pero a priori también parecen ganar los propios vasallos y concejos una vez que el usufructo y la relación con esas tierras, la mayor parte, como vimos, de administración concejil o comunal, hubiera sido muy distinta y en cierto modo más desfavorable de haber sido recuperadas por el Estado para posteriormente ir a parar a la burguesía rentista urbana o rural. La coincidencia de intereses en este momento entre señores y vasallos no es casual, después del proceso desamortizador y de las conocidas pretensiones del Estado liberal. Los campesinos sabían de sobra que los señores se habían apropiado por la fuerza del poder jurisdiccional y en modo alguno poseían títulos de las heredades y espacios que usufructuaban a cambio de unas rentas forales que no se habían modificado en sus cuantías desde la Edad Media. El miedo a perder el control de esos espacios, heredados generación tras generación, y sobre todo a ver incrementada la renta por parte de los posibles nuevos titulares no sólo motivó que los concejos más afectados como Palacios, Santa María de la Isla, Villalís, etc., se apartaran del conflicto judicial, sino que declarasen en él a favor de la parte demandante. Si bien los Bazán -Miranda nunca pudieron llevar a la práctica plena lo contenido en el título señorial referente a su pleno dominio sobre los términos o territorios, al final y una vez que son conscientes de que han perdido la vía más importante de sus ingresos, las alcabalas y rentas enajenadas, ponen todo su empeño y poder en la conservación del dominio directo sobre una parte mínima del territorio. No obstante, la presencia de su dominio territorial y solariego en cada uno de los términos o territorios de los treinta y cinco lugares bajo su jurisdicción va a ser muy desigual ya que ésta va desde la total ausencia en una docena de lugares, hasta la posesión de importante heredades de tierras labradías roturadas y repartidas por los respectivos concejos entre sus vecinos. Estas heredades se sitúan en los pueblos más cercanos al centro de poder, es decir en las villas de La Bañeza y Palacios. La única causa que se nos ofrece a esta desigual situación y a que al final los señores solamente fueran capaces de apropiarse de un porcentaje de tierra que no superó el $5 \%$ del terrazgo productivo de todo el territorio 
jurisdiccional fue la mayor o menor capacidad de respuesta o oposición por parte de los concejos, de forma especial en determinadas fases que pueden situarse en el siglo XV y en la década siguiente al triunfo del bando realista sobre los comuneros, triunfo del que dichos señores fueron los primeros beneficiados junto a la Corona. 
